\title{
New Diphosphane Ligands Based on Bisphenol A Backbones - Synthesis and Coordination Chemistry
}

\author{
Jarl Ivar van der Vlugt, ${ }^{[a]}$ Michiel M. P. Grutters, ${ }^{[a]}$ Allison M. Mills, ${ }^{[b]}$ Huub Kooijman, ${ }^{[b]}$ \\ Anthony L. Spek, ${ }^{[b]}$ and Dieter Vogt*[a]
}

Keywords: Ligand design / Phosphanes / Coordination modes / Structure elucidation / Transition metals

A series of easily accessible diphosphane compounds 1-4, based on bisphenol A derived backbones, has been prepared. A straightforward two-step synthetic route has been employed to obtain these new ligands in good yields from cheap starting materials. Molecular structures for both compound $\mathbf{2}$ and its oxidized form $\left(\mathbf{5} \cdot \mathrm{H}_{2} \mathrm{O}\right)$ have been determined and are discussed in detail. The coordination of ligand 2 to palladium, platinum, and rhodium precursors has been studied by NMR spectroscopy as well as X-ray crystallography. The molecular structures of the face-to-face dimeric

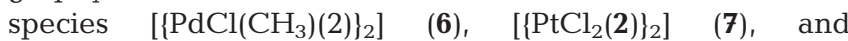
$\left[\{\mathrm{RhCl}(\mathrm{CO})(2)\}_{2}\right](\mathbf{8})$ are described in detail.

(C) Wiley-VCH Verlag GmbH \& Co. KGaA, 69451 Weinheim, Germany, 2003)

\section{Introduction}

The coordination chemistry of diphosphane ligands with a variety of transition metals has been widely studied and several types of coordination modes have been established over the years. ${ }^{[1,2]}$ Numerous families of novel ligands have been synthesized, ${ }^{[3]}$ with emphasis on cis-chelation to form monomeric metal complexes. As well as designing ligands based on desired behaviour towards transition metals and the catalytic activity of the resultant systems, the approach of modular design and availability from cheap resources has gained significant importance.

We have chosen Bisphenol A as a somewhat neglected yet promising starting material for the synthesis of a new ligand class. ${ }^{[4,5]} \mathrm{A}$ wide range of these bisphenols is commercially available at low price since they are used as components in epoxy resins. Generic structures are easily available by simple acid catalyzed condensation of a ketone with two molecules of a phenol. ${ }^{[6]}$ Based on these versatile compounds we employed a straightforward two-step synthetic route to novel P-containing compounds (Scheme 1).

In the first step, the phenol groups were protected by methylation with iodomethane. Subsequently, selective ortho-lithiation of both phenyl rings was followed by reaction with the phosphane source $\mathrm{ClPPh}_{2}$. Filtration and evaporation of the solvent followed by washing of the crude prod-

[a] Schuit Institute of Catalysis, Laboratory of Homogeneous Catalysis, Eindhoven University of Technology,

P. O. Box 513, 5600 MB Eindhoven, The Netherlands

Fax: (internat.) + 31-40-2455054

E-mail: d.vogt@tue.nl

[b] Laboratory for Crystal and Structural Chemistry, Department of Chemistry, Utrecht University,

Padualaan 8, $3584 \mathrm{CH}$, Utrecht, The Netherlands uct with methanol afforded the pure compounds in overall yields of $40-50 \%$. Using this method, we obtained compounds 1-3 based on derivatives of the Bisphenol A backbone. Furthermore, the silicon derivative $\mathbf{4}$ was synthesized in good yield starting from 4-bromoanisole and dichlorodimethylsilane via a modified two-step route. Compounds 1-4 were characterized by ${ }^{1} \mathrm{H},{ }^{13} \mathrm{C}$, and ${ }^{31} \mathrm{P}$ NMR spectroscopy, as well as by elemental analysis. We have previously reported this synthetic route, focussing on the synthesis and catalytic applicability of a ligand derived from 1,2-diphenylbenzene as the backbone. ${ }^{[5]}$

We were able to obtain single crystals, suitable for X-ray analysis, for compounds $\mathbf{1 - 3}$, by recrystallization of the pure solids from hot 1-propanol or hot acetonitrile. Only the molecular structure of compound $\mathbf{2}$ is depicted in Figure 1, while selected bond lengths and bond angles for all three compounds are summarized in Table 1.

Because of the rotational freedom of the aromatic rings in the backbone, the diphenylphosphane groups are not constrained to any particular mutual orientation. Compound 2 shows approximate $C_{2}$ symmetry. The bond distances between the ipso-carbons of the backbone with the phosphorus atoms are normal at around $1.84 \AA\left[\mathrm{P}^{1}-\mathrm{C}^{3}\right.$ $1.840(2) \AA$ and $\left.\mathrm{P}^{2}-\mathrm{C}^{9} 1.845(2) \AA\right]$. The central-carbon $\left(\mathrm{C}^{15}\right)$ of the backbone is clearly tetrahedrally surrounded. The through-space $\mathrm{P}^{1}-\mathrm{O}^{1}$ and $\mathrm{P}^{2}-\mathrm{O}^{2}$ distances are around $2.8-2.9 \AA$. The intramolecular $\mathrm{P}-\mathrm{P}$ distance is $9.7664(8)$ $\AA$ A.

To obtain the corresponding diphosphane oxide, we reacted compound $\mathbf{2}$ with hydrogen peroxide to yield compound 5. In the ${ }^{31} \mathrm{P}$ NMR spectrum a singlet was observed at $\delta=27.7 \mathrm{ppm}$ which is a typical value for a phosphane oxide. ${ }^{[7]}$ We were able to obtain single crystals, suitable for 


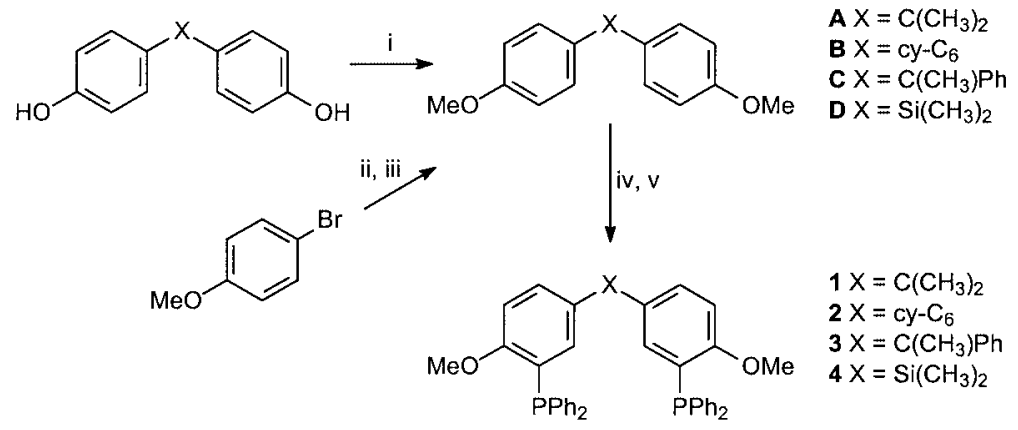

Scheme 1. Synthetic route to BPphos

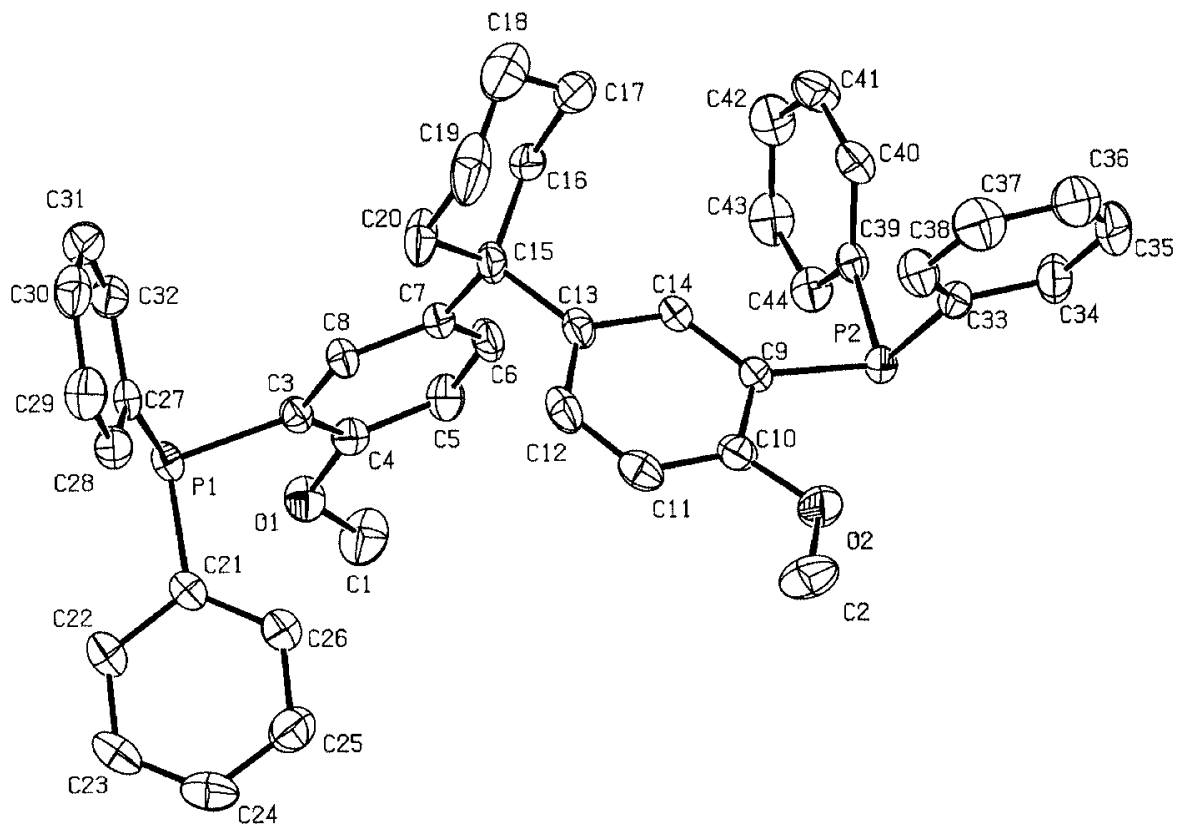

Figure 1. Molecular structure of compound 2

Table 1. Selected bond lengths and angles for compounds $\mathbf{1}-\mathbf{3}$

\begin{tabular}{lccc}
\hline & $\mathbf{1}$ & $\mathbf{2}$ & $\mathbf{3}$ \\
\hline Bond lengths [̊] & & & \\
$\mathrm{P}^{1}-\mathrm{C}^{3}$ & $1.8484(15)$ & $1.840(2)$ & $1.8354(16)$ \\
$\mathrm{P}^{2}-\mathrm{C}^{9}$ & $1.8428(16)$ & $1.845(2)$ & $1.8385(17)$ \\
$\mathrm{O}^{1}-\mathrm{C}^{1}$ & $1.429(2)$ & $1.431(3)$ & $1.413(3)$ \\
$\mathrm{O}^{1}-\mathrm{C}^{4}$ & $1.374(2)$ & $1.370(2)$ & $1.375(2)$ \\
$\mathrm{O}^{2}-\mathrm{C}^{2}$ & $1.429(3)$ & $1.425(3)$ & $1.424(2)$ \\
$\mathrm{O}^{2}-\mathrm{C}^{10}$ & $1.372(2)$ & $1.372(2)$ & $1.376(2)$ \\
$\mathrm{P}^{1}-\mathrm{P}^{2}$ & $9.8510(6)$ & $9.7664(8)$ & $6.7749(6)$ \\
$\mathrm{Angles}\left[{ }^{\circ}\right]$ & & & \\
$\mathrm{C}^{1}-\mathrm{O}^{1}-\mathrm{C}^{4}$ & $117.64(13)$ & $117.52(17)$ & $118.25(14)$ \\
$\mathrm{C}^{2}-\mathrm{O}^{2}-\mathrm{C}^{10}$ & $118.26(14)$ & $117.86(16)$ & $117.61(14)$ \\
$\mathrm{P}^{1}-\mathrm{C}^{3}-\mathrm{C}^{4}$ & $118.25(11)$ & $118.01(14)$ & $116.89(12)$ \\
$\mathrm{P}^{2}-\mathrm{C}^{9}-\mathrm{C}^{10}$ & $117.17(13)$ & $118.72(15)$ & $116.99(13)$ \\
$\mathrm{C}^{7}-\mathrm{C}^{15}-\mathrm{C}^{13}$ & $111.30(13)$ & $106.96(14)$ & $110.23(13)$ \\
\hline
\end{tabular}

X-ray analysis, from a THF solution. The molecular structure is depicted in Figure 2, with selected bond lengths and angles listed in Table 2.

The structure of compound $\mathbf{5}$ represents the diphosphane oxide of $\mathbf{2}$ but with an additional molecule of water present. There is hydrogen-bonding between the oxo groups of com- pound 5 and the hydrogen atoms of the water molecule. ${ }^{[8]}$ The $\mathrm{O}-\mathrm{H} \cdots \mathrm{O}(\mathrm{P})$ contacts are almost equivalent with $\mathrm{H}^{\#}-\mathrm{O}(\mathrm{P})$ bond lengths of $1.99(5) \AA\left(\mathrm{H}^{\#}-\mathrm{O}^{3}\right)$ and 2.01(5) $\AA\left(\mathrm{H}^{\#}-\mathrm{O}^{4}\right)$, which are much smaller than the calculated sum of the van der Waals radii of $2.72 \AA$. The $\mathrm{O}^{5}-\mathrm{O}(\mathrm{P})$ distances are 2.835(7) $\AA\left(\mathrm{O}^{3}-\mathrm{O}^{5}\right)$ and $2.822(7) \AA\left(\mathrm{O}^{4}-\mathrm{O}^{5}\right)$ and the $\mathrm{O}^{5}-\mathrm{H}^{\#}-\mathrm{O}(\mathrm{P})$ angles are $166(5)^{\circ}\left(\mathrm{P}^{1}\right)$ and $168(6)^{\circ}$ $\left(\mathrm{P}^{2}\right)$, respectively. Furthermore, the orientation of the two phosphorus atoms is dramatically altered relative to the structure of the free ligand (vide supra). Due to the template effect of the water molecule, both P-atoms are located on the same side of the molecule with the oxygen atoms pointing towards one another. This leads to a decreased $\mathrm{P}^{1}-\mathrm{P}^{2}$ distance of 6.579(2) $\AA$. The bond lengths between the phosphorus and carbon atoms of the ligand backbone $\left(\mathrm{P}^{1}-\mathrm{C}^{3}\right.$ and $\left.\mathrm{P}^{2}-\mathrm{C}^{9}\right)$ are slightly shorter than the corresponding distances in compound $\mathbf{2}$, due to a decrease of electron density on the phosphorus atoms in the oxidized state. The $\mathrm{P}-\mathrm{O}$ bond lengths found for both phosphane oxide moieties, 1.491(4) $\AA\left(\mathrm{P}^{1}-\mathrm{O}^{3}\right)$ and 1.492(5) $\AA$ $\left(\mathrm{P}^{2}-\mathrm{O}^{4}\right)$, are similar to those found in triphenylphosphane oxide hemihydrate ${ }^{[8]}$ and tris( $p$-tolyl)phosphane oxide ${ }^{[9]}$ but slightly lower in comparison with the mono oxide of 


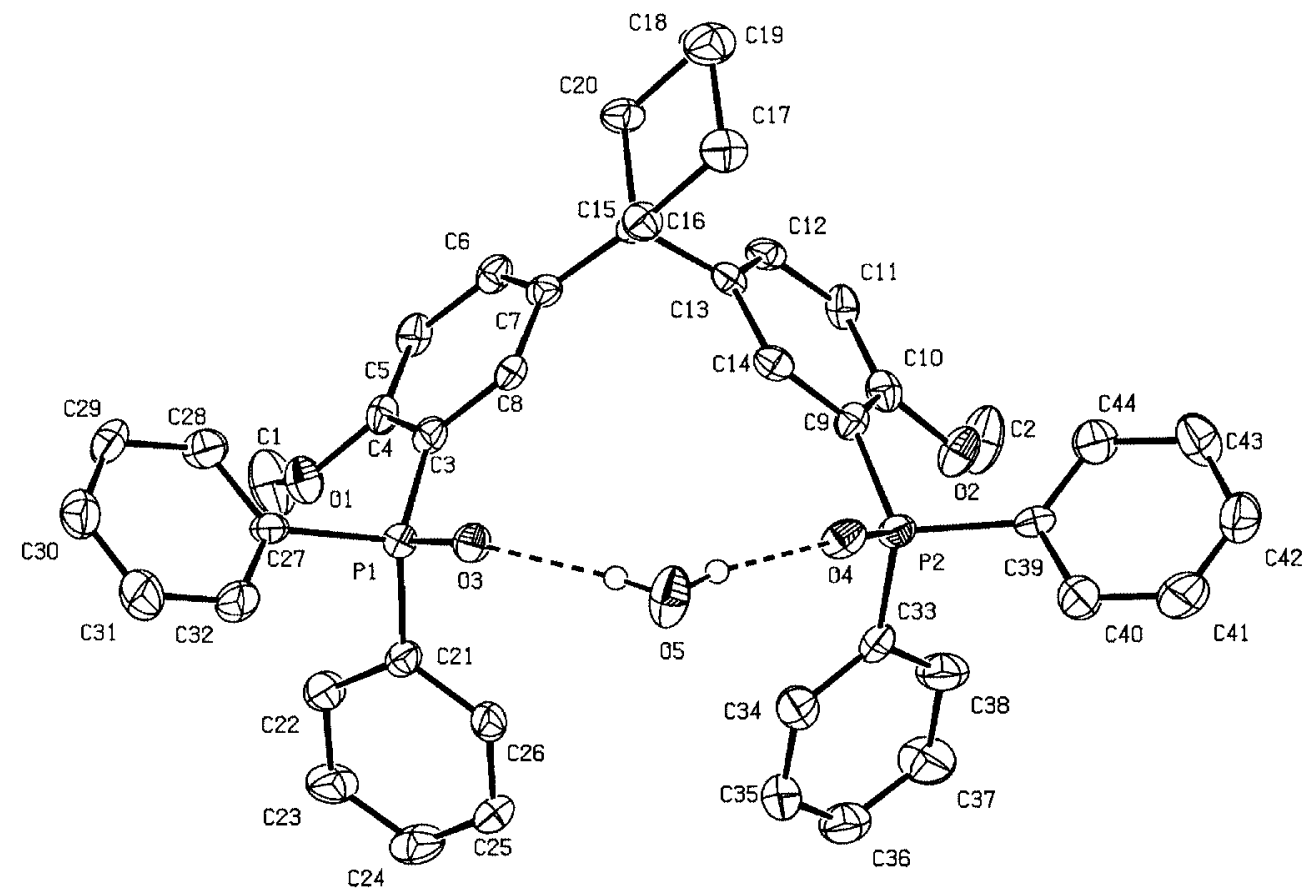

Figure 2. Crystal structure of compound $\mathbf{5}$

Table 2. Selected bond lengths and angles for compound $\mathbf{5} \cdot \mathrm{H}_{2} \mathrm{O}$

\begin{tabular}{llll}
\hline Bond lengths $[\AA]$ & \multicolumn{2}{c}{ Angles $\left[^{\circ}\right]$} \\
\hline $\mathrm{P}^{1}-\mathrm{C}^{3}$ & $1.810(7)$ & $\mathrm{C}^{1}-\mathrm{O}^{1}-\mathrm{C}^{4}$ & $117.4(6)$ \\
$\mathrm{P}^{2}-\mathrm{C}^{9}$ & $1.803(9)$ & $\mathrm{C}^{2}-\mathrm{O}^{2}-\mathrm{C}^{10}$ & $118.9(6)$ \\
$\mathrm{O}^{1}-\mathrm{C}^{1}$ & $1.427(9)$ & $\mathrm{P}^{1}-\mathrm{C}^{3}-\mathrm{C}^{4}$ & $125.4(5)$ \\
$\mathrm{O}^{1}-\mathrm{C}^{4}$ & $1.378(8)$ & $\mathrm{P}^{2}-\mathrm{C}^{9}-\mathrm{C}^{10}$ & $125.6(5)$ \\
$\mathrm{O}^{2}-\mathrm{C}^{2}$ & $1.416(9)$ & $\mathrm{C}^{7}-\mathrm{C}^{15}-\mathrm{C}^{13}$ & $105.1(5)$ \\
$\mathrm{O}^{2}-\mathrm{C}^{10}$ & $1.383(9)$ & $\mathrm{O}^{3}-\mathrm{P}^{1}-\mathrm{C}^{3}$ & $110.1(3)$ \\
$\mathrm{P}^{1}-\mathrm{O}^{3}$ & $1.491(4)$ & $\mathrm{O}^{4}-\mathrm{P}^{2}-\mathrm{C}^{9}$ & $109.9(3)$ \\
$\mathrm{P}^{2}-\mathrm{O}^{4}$ & $1.492(5)$ & & \\
$\mathrm{P}^{1}-\mathrm{P}^{2}$ & $6.579(2)$ & & \\
\hline
\end{tabular}

BINAP. ${ }^{[10]}$ We are currently investigating the inclusion of other molecules capable of forming hydrogen bonds in order to form three-dimensional networks. The coordination behaviour of the phosphane oxide, which is still a weakly coordinating group, ${ }^{[11]}$ has also been studied.

We were interested in the coordination of the novel diphosphane compounds to various transition metals and, in particular, whether the chelate ring size of 9 atoms (including the two P-atoms) would have implications for the mode of coordination and if bidentate mononuclear complexes would be formed.

Rauchfuss et al. have already investigated the monophosphane (diphenylphosphanyl)anisole and they concluded that coordination to a metal, such as palladium and platinum, took place only through the phosphorus. ${ }^{[12]}$ In order to study the coordination chemistry of the new family of BPphos ligands to $\mathrm{Pd}, \mathrm{Pt}$, and $\mathrm{Rh}$, we used ligand $\mathbf{2}$ as a representative example. Marty et al. have reported some experimental evidence for the formation of a monomeric, trans-coordinated $\mathrm{PdCl}_{2}$ complex using 3,3'-oxybis[(diphenylphosphanyl)methyl]benzene, which is structurally related to compounds $\mathbf{1}-\mathbf{4} .^{[13]}$

From the reaction of $\mathbf{2}$ with $\left[\mathrm{PdClCH}_{3}(\mathrm{cod})\right]$ as a starting material, only a singlet at $\delta=25.0 \mathrm{ppm}$ was observed in the ${ }^{31} \mathrm{P}$ NMR spectrum. In the ${ }^{1} \mathrm{H}$ NMR spectrum, a broad triplet was present at $\delta=-0.05 \mathrm{ppm}$ and a singlet at $\delta=$ $3.8 \mathrm{ppm}$ was seen in the ${ }^{13} \mathrm{C}$ NMR spectrum. These observations are clear indications that a trans-coordinated species is present, either monomeric or dimeric. For monomeric trans-coordinated $\left[\mathrm{PdClCH}_{3}(\mathrm{Xantphos})\right]$ complexes, Zuideveld et al. have reported proton methyl signals at around $\delta=-0.2$ ppm. ${ }^{[14]}$ Upon slow evaporation of the deuterated solvent, yellow block-shaped single crystals, suitable for Xray analysis, were obtained for this compound. The crystallographic study undertaken, indicated formation of the dimeric macrocyclic complex $\mathbf{6}$ which did indeed display a trans-coordination for each of the two phosphorus atoms and two bridging palladium atoms. The molecular structure of complex 6 is depicted in Figure 3, while Table 3 contains selected bond lengths and bond angles.

The complex is centrosymmetric and the geometry around the palladium atoms is distorted square planar, as indicated by the corresponding angles listed in Table 2. The $\mathrm{P}^{1}-\mathrm{Pd}-\mathrm{P}^{2}$ angle is $172.94(3)^{\circ}$, while the $\mathrm{C}^{1}-\mathrm{Pd}^{1}-\mathrm{Cl}^{1}$ angle is $171.64(13)^{\circ}$. The $\mathrm{Pd}-\mathrm{P}$ bond lengths of 2.3250(9) $\AA$ $\left(\mathrm{Pd}-\mathrm{P}^{1}\right)$ and $2.3248(9) \AA\left(\mathrm{Pd}-\mathrm{P}^{2}\right)$ are typical for triarylphosphanes ${ }^{[15,16]}$ as are the lengths of the palladium to chlorine and palladium to methyl bonds. ${ }^{[17]}$ The $\mathrm{P}^{1}-\mathrm{P}^{2 \mathrm{a}}$ distance was found to be 7.4470(13) А. Other binuclear palladium complexes with a face-to-face structure that have been described in literature most often have two chlorine ligands coordinated to the metal center instead of one 


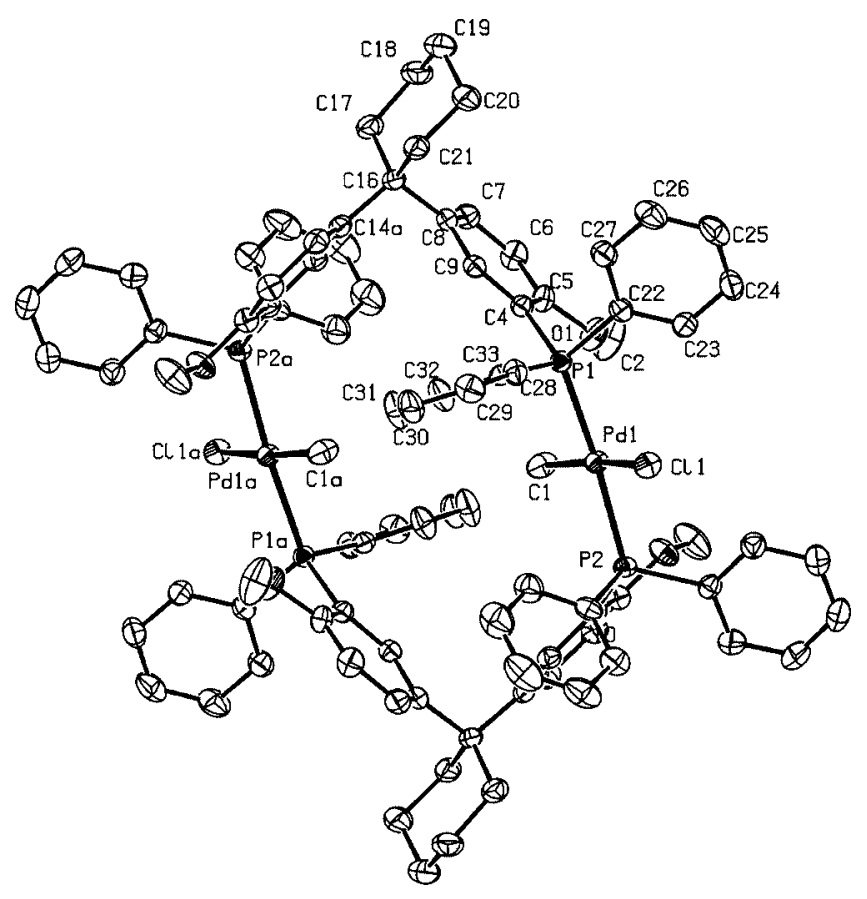

Figure 3. X-ray structure of complex 6

Table 3. Selected bond lengths and angles for complex $\mathbf{6}$, trans, trans- $\left[\left\{\mathrm{PdCl}\left(\mathrm{CH}_{3}\right)(\mu-2)\right\}_{2}\right]$

\begin{tabular}{llll}
\hline \multicolumn{2}{c}{ Bond lengths $[\AA]$} & \multicolumn{2}{c}{ Angles $\left[^{\circ}\right]$} \\
\hline $\mathrm{Pd}^{1}-\mathrm{P}^{1}$ & $2.3250(9)$ & $\mathrm{P}^{1}-\mathrm{Pd}^{1}-\mathrm{P}^{2}$ & $172.94(3)$ \\
$\mathrm{Pd}^{1}-\mathrm{P}^{2}$ & $2.3248(9)$ & $\mathrm{C}^{1}-\mathrm{Pd}^{1}-\mathrm{Cl}^{1}$ & $171.64(13)$ \\
$\mathrm{Pd}^{1}-\mathrm{Cl}^{1}$ & $2.4330(10)$ & $\mathrm{P}^{1}-\mathrm{Pd}^{1}-\mathrm{Cl}^{1}$ & $88.18(3)$ \\
$\mathrm{Pd}^{1}-\mathrm{C}^{1}$ & $2.075(4)$ & $\mathrm{P}^{2}-\mathrm{Pd}^{1}-\mathrm{Cl}^{1}$ & $88.41(3)$ \\
$\mathrm{P}^{1}-\mathrm{C}^{4}$ & $1.836(3)$ & $\mathrm{P}^{1}-\mathrm{Pd}^{1}-\mathrm{C}^{1}$ & $92.30(9)$ \\
$\mathrm{P}^{2}-\mathrm{C}^{10}$ & $1.830(3)$ & $\mathrm{P}^{2}-\mathrm{Pd}^{1}-\mathrm{C}^{1}$ & $90.17(9)$ \\
$\mathrm{P}^{1}-\mathrm{P}^{2 \mathrm{a}}$ & $7.4470(13)$ & $\mathrm{C}^{8}-\mathrm{C}^{16}-\mathrm{C}^{14 a}$ & $105.2(3)$ \\
$\mathrm{Pd}^{1}-\mathrm{Pd}^{1 \mathrm{a}}$ & $7.4972(4)$ & & \\
\hline
\end{tabular}

chlorine and one methyl ligand. ${ }^{[18,19]}$ Davies et al. have described the face-to-face dimer $\left[\mathrm{Pd}_{2} \mathrm{Cl}_{2}\left(\mathrm{CH}_{2} \mathrm{NO}_{2}\right)(\mu\right.$ $\left.\mathrm{dmpm})_{2}\right]\left(\mathrm{dmpm}=\mathrm{Me}_{2} \mathrm{PCH}_{2} \mathrm{PMe}_{2}\right)$. The bond lengths between the palladium and the chlorine or the carbon atom of the nitromethyl group turned out to be slightly shorter than in the case of complex $\mathbf{6}$, due to the electronic withdrawing effect of the nitro unit. ${ }^{[20]}$ Only very recently the group of James published the synthesis and structural characterization of the $\mathrm{Pd}_{2} \mathrm{Cl}_{4}$ derivative of dmpm. ${ }^{[20 \mathrm{~b}]}$ Kemmitt and co-workers quite recently reported various dimeric palladium-diphosphane complexes with a chlorine and a phenyl group attached to the palladium atoms. ${ }^{[16]}$

In order to verify if the formation of face-to-face dimeric complexes is always favoured, regardless of the transition metal, we decided to study the complexation of ligand $\mathbf{2}$ with a platinum precursor. After reaction with $\left[\mathrm{PtCl}_{2}\left(\mathrm{CH}_{3} \mathrm{CN}\right)_{2}\right]$, an off-white solid was obtained. After dissolving this compound in acetone and slow evaporation of the solvent, one product could be isolated as yellow single crystals in good yield. The ${ }^{31} \mathrm{P}$ NMR spectrum of this compound showed a singlet at $\delta=15.8 \mathrm{ppm}$, flanked by
${ }^{195} \mathrm{Pt}$-satellites, and a coupling constant $J_{\mathrm{Pt}-\mathrm{P}}$ of $2705 \mathrm{~Hz}$. This clearly indicates a trans-coordination of two phosphorus atoms. ${ }^{[21]}$ These block-shaped crystals turned out to be suitable for X-ray analysis. The molecular structure for complex 7 is depicted in Figure 4. Selected bond lengths and bond angles are listed in Table 4 .

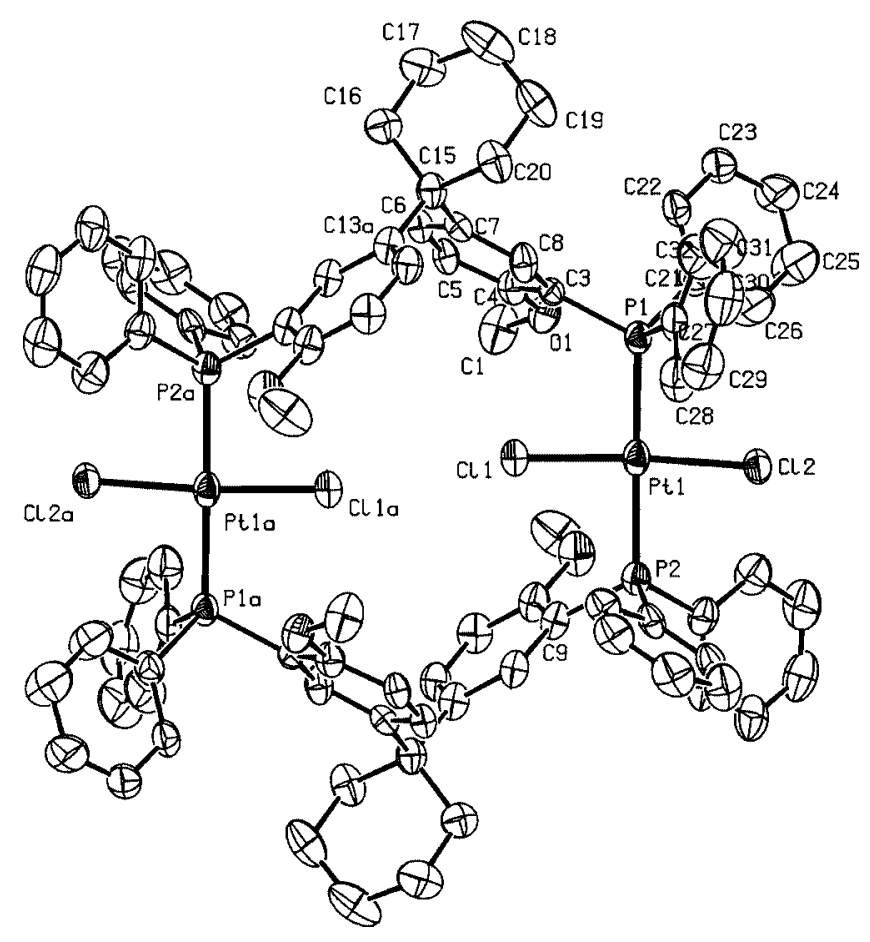

Figure 4. X-ray structure of complex 7

Table 4. Selected bond lengths and angles for complex 7,

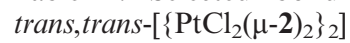

\begin{tabular}{lllr}
\hline Bond lengths $[\AA]$ & \multicolumn{2}{c}{ Angles $\left[^{\circ}\right]$} \\
\hline $\mathrm{Pt}^{1}-\mathrm{P}^{1}$ & $2.320(2)$ & $\mathrm{P}^{1}-\mathrm{Pt}^{1}-\mathrm{P}^{2}$ & $176.78(7)$ \\
$\mathrm{Pt}^{1}-\mathrm{P}^{2}$ & $2.315(2)$ & $\mathrm{P}^{1}-\mathrm{Pt}^{1}-\mathrm{Cl}^{1}$ & $92.33(8)$ \\
$\mathrm{Pt}^{1}-\mathrm{Cl}^{1}$ & $2.294(2)$ & $\mathrm{P}^{1}-\mathrm{Pt}^{1}-\mathrm{Cl}^{2}$ & $90.09(7)$ \\
$\mathrm{Pt}^{1}-\mathrm{Cl}^{2}$ & $2.3270(18)$ & $\mathrm{Cl}^{1}-\mathrm{Pt}^{1}-\mathrm{Cl}^{2}$ & $171.77(7)$ \\
$\mathrm{P}^{1}-\mathrm{C}^{3}$ & $1.835(7)$ & $\mathrm{P}^{2}-\mathrm{Pt}^{1}-\mathrm{Cl}^{1}$ & $88.80(7)$ \\
$\mathrm{P}^{2}-\mathrm{C}^{9}$ & $1.827(7)$ & $\mathrm{P}^{2}-\mathrm{Pt}^{1}-\mathrm{Cl}^{2}$ & $88.38(7)$ \\
$\mathrm{P}^{1}-\mathrm{P}^{2 \mathrm{a}}$ & $8.627(3)$ & $\mathrm{C}^{7}-\mathrm{C}^{15}-\mathrm{C}^{13 \mathrm{a}}$ & $108.9(7)$ \\
$\mathrm{Pt}^{1}-\mathrm{Pt}^{1 \mathrm{a}}$ & $8.6391(5)$ & & \\
\hline
\end{tabular}

Like the palladium complex $\mathbf{6}$, the molecular structure of complex 7 also turned out to be dimeric and centrosymmetric. The geometry around the platinum atoms is distorted square planar, with a $\mathrm{P}^{1}-\mathrm{Pt}-\mathrm{P}^{2}$ angle of $176.78(7)^{\circ}$ and a $\mathrm{Cl}^{1}-\mathrm{Pt}-\mathrm{Cl}^{2}$ angle of $171.77(7)^{\circ}$. The geometry around the central atom $\mathrm{C}^{15}$ of the ligand backbone is nearly perfectly tetrahedral, as indicated by the angle of $108.9(7)^{\circ}$ for both phenyl rings. Interestingly, the $\mathrm{P}^{1}-\mathrm{P}^{2 \mathrm{a}}$ distance of 8.627(3) $\AA$ is larger than in the palladium-dimer 6. The $\mathrm{P}-\mathrm{Pt}$ and $\mathrm{Cl}-\mathrm{Pt}$ bond lengths are in their expected ranges, compared with similar structures previously reported. ${ }^{[22,23]}$ Wood et al. showed that the reaction of 2,6bis(diphenylphosphanyl)pyridine with $\mathrm{PtCl}_{2}$ yielded a cis- 
dimer. When the chlorine-ligands were substituted for iodine-ligands, however, the phosphorus atoms were coordinated in a trans-fashion. ${ }^{[24]}$

To further understand the formation of these face-to-face dimers, we chose the rhodium precursor $[\{\mathrm{Rh}(\mu-$ $\left.\mathrm{Cl})(\mathrm{CO})_{2}\right\}_{2}$ ]. Complexes prepared from this metal source normally exhibit a trans-coordination for the phosphorus atoms. After reaction of this rhodium species with ligand 2, a doublet was observed in the ${ }^{31} \mathrm{P}$ NMR spectrum at $\delta=$ $23.7 \mathrm{ppm}$, with a coupling constant $J_{\mathrm{Rh}-\mathrm{P}}$ of $128.3 \mathrm{~Hz}$. This value is typical of those seen in rhodium diphenylphosphane complexes. ${ }^{[25]}$ In the carbonyl region of the IR spectrum (ATR-mode) obtained from the solid product, the CO-stretching vibration was present at $v_{\mathrm{CO}}=1976 \mathrm{~cm}^{-1}$. This is in good agreement with the value of $v_{\mathrm{CO}}=1974$ $\mathrm{cm}^{-1}$ reported for $\left[\mathrm{RhCl}(\mathrm{CO})\left\{\mathrm{P}(o-\mathrm{An}) \mathrm{Ph}_{2}\right\}\right](\mathrm{An}=$ anisole). ${ }^{[26]}$ Compared with the value of $v_{\mathrm{CO}}=1982 \mathrm{~cm}^{-1}$ found for $\left[\mathrm{RhCl}(\mathrm{CO})\left\{\mathrm{PPh}_{2}\left(\mathrm{C}_{6} \mathrm{~F}_{5}\right)\right\}\right]^{[27]}$ and $v_{\mathrm{CO}}=1980$ $\mathrm{cm}^{-1}$ for $\left[\mathrm{Rh}(\mathrm{Cl})(\mathrm{CO})\left(\mathrm{PPh}_{3}\right)_{2}\right]^{[28]}$, the value found for our $\mathrm{Rh}$ complex is slightly low. Note: Moloy and Petersen have touched upon the discrepancy arising in literature with respect to the $\mathrm{CO}$ stretching frequency for $\left[\mathrm{Rh}(\mathrm{Cl})(\mathrm{CO})\left(\mathrm{PPh}_{3}\right)_{2}\right]$. Their own experiments showed a single band at $v_{\mathrm{CO}}=1965 \mathrm{~cm}^{-1}$ in $\mathrm{CH}_{2} \mathrm{Cl}_{2} \cdot{ }^{[29]}$ The value of $1976 \mathrm{~cm}^{-1}$ demonstrates that the ligands from the BPphos family are slightly more basic than the aforementioned two ligand systems. However the value is signifcantly higher than that found for $\mathrm{Rh}(\mathrm{Cl})(\mathrm{CO})$ complexes with alkyldiarylphosphanes such as those described by Zhang et al. ${ }^{[30]}$ and by the group of Dilworth $\left(v=1957 \mathrm{~cm}^{-1}\right){ }^{[31]}$

By slow diffusion of acetonitrile into a dichloromethane solution of the compound, single crystals could be grown that were suitable for an X-ray crystallographic study. The molecular structure for centrosymmetric complex $\mathbf{8}$ is shown in Figure 5. Similar to the Pd and Pt complexes, a face-to-face dimeric structure can be observed. Selected bond lengths and bond angles are listed in Table 5.

The geometry around the rhodium atoms is distorted square planar, with a $\mathrm{P}-\mathrm{Rh}-\mathrm{P}$ angle of $171.01(3)^{\circ}$ and a $\mathrm{Cl}-\mathrm{Rh}-\mathrm{C}(\mathrm{O})$ angle of $176.99(7)^{\circ}$. These distances are in the expected range with an average $\mathrm{Rh}-\mathrm{P}$ bond length of $2.32 \AA$. The $\mathrm{Rh}-\mathrm{Cl}$ and $\mathrm{Rh}-\mathrm{C}(\mathrm{O})$ bond lengths are $2.3795(5) \AA$ and $1.810(2) \AA$, respectively. The $\mathrm{C}-\mathrm{O}$ distance is typical at $1.145(2) \AA .{ }^{[30-34]}$ The $\mathrm{P}^{1}-\mathrm{P}^{2 \mathrm{a}}$ distance of 8.8150(12) $\AA$ as well as the corresponding $\mathrm{Rh}-\mathrm{Rh}$ distance of $9.0005(11) \AA$ are in the range found for the palladium and platinum complexes.

Many trans-[RhCl(CO)] complexes with (di)phosphane ligands have been described in the literature, yet most of these systems are solely mononuclear. Relatively few examples are known where a dimeric compound has been formed exclusively and subsequently structurally characterized by X-ray crystallography. ${ }^{[35-39]}$

In summary, we have described the easy synthesis of a new class of diphosphane ligands based on commercially available, cheap raw materials derived from Bisphenol A and in good overall yields. In addition to NMR spectroscopy, X-ray crystallography has been used to study the

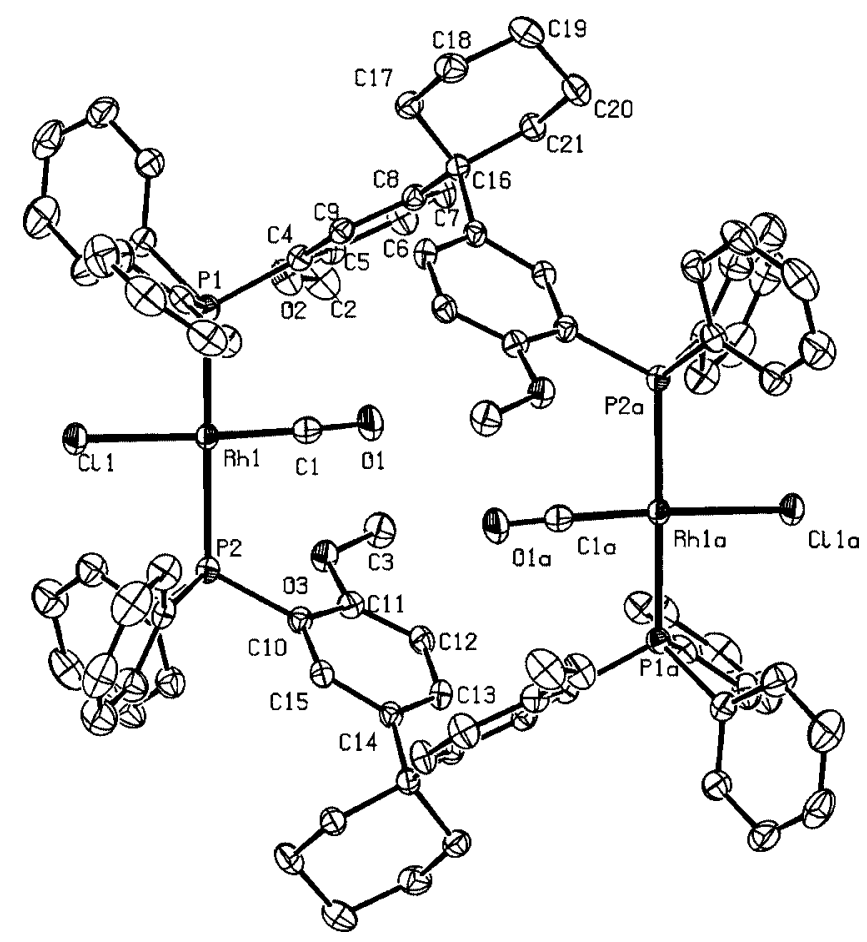

Figure 5. X-ray structure of complex 8

Table 5. Selected bond lengths and angles for complex 8, trans,trans-[\{RhCl(CO)( $\left.\left.\mu-2)_{2}\right\}_{2}\right]$

\begin{tabular}{lllr}
\hline Bond lengths [̊] & \multicolumn{2}{c}{ Angles [ $\left.{ }^{\circ}\right]$} \\
\hline $\mathrm{Rh}^{1}-\mathrm{P}^{1}$ & $2.3153(5)$ & $\mathrm{P}^{1}-\mathrm{Rh}^{1}-\mathrm{P}^{2}$ & $171.01(3)$ \\
$\mathrm{Rh}^{1}-\mathrm{P}^{2}$ & $2.3345(6)$ & $\mathrm{P}^{1}-\mathrm{Rh}^{1}-\mathrm{Cl}^{1}$ & $87.85(3)$ \\
$\mathrm{Rh}^{1}-\mathrm{Cl}^{1}$ & $2.3795(5)$ & $\mathrm{P}^{2}-\mathrm{Rh}^{1}-\mathrm{Cl}^{1}$ & $90.36(3)$ \\
$\mathrm{Rh}^{1}-\mathrm{C}^{1}$ & $1.810(2)$ & $\mathrm{Cl}^{1}-\mathrm{Rh}^{1}-\mathrm{C}^{1}$ & $176.99(7)$ \\
$\mathrm{C}^{1}-\mathrm{O}^{1}$ & $1.145(2)$ & $\mathrm{P}^{1}-\mathrm{Rh}^{1}-\mathrm{C}^{1}$ & $89.80(7)$ \\
$\mathrm{P}^{1}-\mathrm{C}^{4}$ & $1.8349(17)$ & $\mathrm{P}^{2}-\mathrm{Rh}^{1}-\mathrm{C}^{1}$ & $92.24(7)$ \\
$\mathrm{P}^{2}-\mathrm{C}^{10}$ & $1.8352(18)$ & $\mathrm{Rh}^{1}-\mathrm{C}^{1}-\mathrm{O}^{1}$ & $177.33(18)$ \\
$\mathrm{P}^{1}-\mathrm{P}^{2 \mathrm{a}}$ & $8.8150(12)$ & $\mathrm{Rh}^{1}-\mathrm{P}^{1}-\mathrm{C}^{4}$ & $116.75(6)$ \\
$\mathrm{Rh}^{1}-\mathrm{Rh}^{1 \mathrm{a}}$ & $9.0005(11)$ & $\mathrm{C}^{8}-\mathrm{C}^{16}-\mathrm{C}^{14 \mathrm{a}}$ & $110.19(15)$ \\
\hline
\end{tabular}

structural differences between compound $\mathbf{2}$ and its oxidised form, $\mathbf{5}$. In the structure of the latter compound, water acts as a template orientating both phosphorus-atoms to the same side of the molecule in the same direction. Complexation studies undertaken with ligand 2 yielded face-toface dimeric macrocycles with palladium, platinum and rhodium, as was shown by NMR spectroscopy as well as X-ray crystallography.

We are currently investigating the options available for modifying the ligand backbone to further control and enforce a certain orientation of the phosphane-moieties as well as the modification of these ligands in order to gain access to chelating variants.

\section{Experimental Section}

Chemicals were purchased from Aldrich, Acros, and Merck and used as received. All preparations were carried out under an argon 
atmosphere using standard Schlenk techniques. Solvents were distilled from sodium/benzophenone (THF, diethyl ether, toluene, hexanes, and ethanol) or calcium hydride $\left(\mathrm{CH}_{2} \mathrm{Cl}_{2}\right.$ and $\left.\mathrm{CDCl}_{3}\right)$ prior to use. $\left[\mathrm{PdCl}_{2}(\mathrm{cod})\right],{ }^{[40]}[\mathrm{PdClMe}(\operatorname{cod})]^{[41]}$ and $\left[\mathrm{PtCl}_{2}(\mathrm{cod})\right]^{[42]}$ were synthesized according to literature procedures. All glassware was dried by heating under vacuum. The NMR spectra were recorded on a Varian Mercury 400 spectrometer $\left({ }^{1} \mathrm{H},{ }^{13} \mathrm{C}\left\{{ }^{1} \mathrm{H}\right\},{ }^{31} \mathrm{P}\left\{{ }^{1} \mathrm{H}\right\}\right)$. Chemical shifts are given in ppm referenced to the deuterated solvent $\left({ }^{1} \mathrm{H},{ }^{13} \mathrm{C}\left\{{ }^{1} \mathrm{H}\right\}\right)$ or $85 \% \mathrm{H}_{3} \mathrm{PO}_{4}\left({ }^{31} \mathrm{P}\left\{{ }^{1} \mathrm{H}\right\}\right)$.

2,2-Bis(4-methoxyphenyl)propane (A): This is a modification of the literature procedure. ${ }^{[43]}$ To a solution of Bisphenol A [2,2'-bis(4hydroxyphenyl)propane] $(11.48 \mathrm{~g}, 0.050 \mathrm{~mol})$ in acetone $(120 \mathrm{~mL})$ were added $\mathrm{K}_{2} \mathrm{CO}_{3}(27.69 \mathrm{~g}, 0.20 \mathrm{~mol})$ and $\mathrm{CH}_{3} \mathrm{I}(21.69 \mathrm{~g}, 0.15$ $\mathrm{mol})$ as well as $\mathrm{NBu}_{4} \mathrm{I}(0.88 \mathrm{~g}, 2.38 \mathrm{mmol})$. The heterogeneous mixture was stirred for $16 \mathrm{~h}$ under reflux. The suspension was filtered through celite and poured into a mixture of diethyl ether $(100 \mathrm{~mL})$ and a $15 \mathrm{w} \%$ aqueous $\mathrm{KOH}$ solution $(100 \mathrm{~mL})$. The organic phase was further washed with saturated brine $(100 \mathrm{~mL})$ and water $(50 \mathrm{~mL})$ after which $\mathrm{MgSO}_{4}$ was added and the organic phase stirred for about $10 \mathrm{~h}$. After filtration through Celite the solvent was removed in vacuo and ethanol $(40 \mathrm{~mL})$ was added to the remaining oil. After stirring, the ethanol was removed in vacuo to yield a pure off-white powder (9.44 g, $36.8 \mathrm{mmol})(73 \%) .{ }^{1} \mathrm{H}$ NMR (400 MHz, $\left.\mathrm{CDCl}_{3}, 300 \mathrm{~K}, \mathrm{ppm}\right): \delta=1.65\left(\mathrm{~s}, 6 \mathrm{H}, \mathrm{CCH}_{3}\right), 3.79(\mathrm{~s}$, $\left.6 \mathrm{H}, \mathrm{OCH}_{3}\right), 6.81\left(\mathrm{~d},{ }^{1} J=8.8 \mathrm{~Hz}, 4 \mathrm{H}, m-\mathrm{H}^{2}\right), 7.15\left(\mathrm{~d},{ }^{1} J=8.8 \mathrm{~Hz}\right.$, $4 \mathrm{H}, o-\mathrm{H}^{1}$ ) (Numbering scheme see Figure 6). ${ }^{13} \mathrm{C}$ NMR $(100 \mathrm{MHz}$, $\left.\mathrm{CDCl}_{3}, 300 \mathrm{~K}, \mathrm{ppm}\right): \delta=31.1,41.6,55.2,113.2,127.7,143.1$, 157.4.

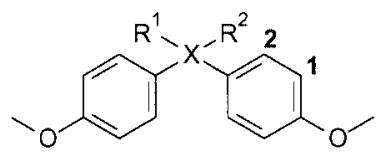

Figure 6. Numbering scheme for protons $\mathrm{H}^{1}$ and $\mathrm{H}^{2}$ of compounds A-D

1,1-Bis(4-methoxyphenyl)cyclohexane (B): This is a modification of the literature procedure. ${ }^{[44]}$ Starting from Bisphenol $Z$ [1,1-bis(4hydroxyphenyl)cyclohexane] (28.8 g, $0.11 \mathrm{~mol})$, compound $\mathbf{B}$ was obtained as a white crystalline solid, using the same procedure as described for A. Yield 83.5\% (27.7 g, 93.5 mmol). ${ }^{1} \mathrm{H}$ NMR (400 MHz, $\left.\mathrm{CDCl}_{3}, 300 \mathrm{~K}, \mathrm{ppm}\right): \delta=1.55$ (m, $6 \mathrm{H}, m-, p-\mathrm{CH}_{2}, c-$ $\left.\mathrm{C}^{6}\right), 2.23\left(\mathrm{~m}, 4 \mathrm{H}, o-\mathrm{CH}_{2}, c-\mathrm{C}^{6}\right), 3.77\left(\mathrm{~s}, 6 \mathrm{H}, \mathrm{OCH}_{3}\right), 6.81\left(\mathrm{~d},{ }^{1} \mathrm{~J}=\right.$ $\left.8.8 \mathrm{~Hz}, 4 \mathrm{H}, m-\mathrm{H}^{2}\right), 7.18\left(\mathrm{~d},{ }^{1} J=8.8 \mathrm{~Hz}, 4 \mathrm{H}, o-\mathrm{H}^{1}\right) .{ }^{13} \mathrm{C} \mathrm{NMR}$ $\left(100 \mathrm{MHz}, \mathrm{CDCl}_{3}, 300 \mathrm{~K}, \mathrm{ppm}\right): \delta=22.9,26.4,37.4,45.0,55.1$, 113.4, 128.0, 141.0, 157.1.

2,2-Bis(4-methoxyphenyl)ethylbenzene (C): This is a modification of the literature procedure. ${ }^{[45]}$ Starting from Bisphenol AP $\{[2,2$-bis(4hydroxyphenyl)ethyl]benzene\} (20.0 g, $68.9 \mathrm{mmol})$, compound C was obtained as a pure off-white powder, using the same procedure as described for A. Yield 64\% (13.92 g, $43.7 \mathrm{mmol}) .{ }^{1} \mathrm{H}$ NMR (400 MHz, $\left.\mathrm{CDCl}_{3}, 300 \mathrm{~K}, \mathrm{ppm}\right): \delta=2.14\left[\mathrm{~s}, 6 \mathrm{H}, \mathrm{C}\left(\mathrm{CH}_{3}\right)\right], 3.79$, $\left(\mathrm{s}, 6 \mathrm{H}, \mathrm{OCH}_{3}\right), 6.79\left(\mathrm{~d},{ }^{1} J=8.8 \mathrm{~Hz}, 4 \mathrm{H}, \mathrm{H}^{2}\right), 7.00\left(\mathrm{~d},{ }^{1} J=8.8 \mathrm{~Hz}\right.$, $\left.4 \mathrm{H}, \mathrm{H}^{1}\right), 7.09(\mathrm{~m}, 2 \mathrm{H}, o-\mathrm{CH}, \mathrm{Ph}), 7.20(\mathrm{~m}, 1 \mathrm{H}, p-\mathrm{CH}, \mathrm{Ph}), 7.26$ (m, $2 \mathrm{H}, m-\mathrm{CH}, \mathrm{Ph}) .{ }^{13} \mathrm{C} \mathrm{NMR}\left(100 \mathrm{MHz}, \mathrm{CDCl}_{3}, 300 \mathrm{~K}, \mathrm{ppm}\right)$ : $\delta=30.7,55.2,113.1,125.8,127.8,128.6,129.7,141.5,157.6$.

Bis(4-methoxyphenyl)dimethylsilane (D): This is a modification of the literature procedure. ${ }^{[46]}$ 4-Bromoanisole $(5.79 \mathrm{~g}, 0.031 \mathrm{mmol})$ was dissolved in THF $(100 \mathrm{~mL})$ and the solution was cooled to $-78{ }^{\circ} \mathrm{C}$ whereupon $n \operatorname{BuLi}(2.5 \mathrm{M}$ solution in hexanes) $(12.4 \mathrm{~mL}$, $31.0 \mathrm{mmol}$ ) was added dropwise by syringe. The reaction mixture was stirred for $1 \mathrm{~h}$ followed by addition of $\mathrm{SiCl}_{2}\left(\mathrm{CH}_{3}\right)_{2}(2.0 \mathrm{~g}$, $31.0 \mathrm{mmol}$ ) by syringe. The reaction mixture was allowed to warm up to room temp. and stirring was continued for about $10 \mathrm{~h}$. Solvents were removed in vacuo and the crude product was dissolved in $\mathrm{CH}_{2} \mathrm{Cl}_{2}(30 \mathrm{~mL})$. Washing with distilled water $(40 \mathrm{~mL})$ afforded a turbid white organic layer. The organic phase was separated and the solvent removed in vacuo to leave a yellow oil. Upon addition of hexanes $(25 \mathrm{~mL})$, a brown precipitate was formed. The solution was isolated and dried with $\mathrm{MgSO}_{4}$. After filtration and subsequent removal of solvent, an off-white solid was obtained. Yield $71 \%$ (3.00 g, $22.0 \mathrm{mmol}) .{ }^{1} \mathrm{H} \mathrm{NMR}\left(400 \mathrm{MHz}, \mathrm{CDCl}_{3}, 300 \mathrm{~K}, \mathrm{ppm}\right)$ : $\delta=0.54\left[\mathrm{~s}, 6 \mathrm{H}, \mathrm{Si}\left(\mathrm{CH}_{3}\right)\right], 3.83\left(\mathrm{~s}, 6 \mathrm{H}, \mathrm{OCH}_{3}\right), 6.93\left(\mathrm{~d},{ }^{1} J=\right.$ $\left.8.8 \mathrm{~Hz}, 4 \mathrm{H}, \mathrm{H}^{2}\right), 7.48\left(\mathrm{~d},{ }^{1} \mathrm{~J}=8.8 \mathrm{~Hz}, 4 \mathrm{H}, \mathrm{H}^{1}\right) .{ }^{13} \mathrm{C} \mathrm{NMR}$ $\left(100 \mathrm{MHz}, \mathrm{CDCl}_{3}, 300 \mathrm{~K}, \mathrm{ppm}\right): \delta=-2.0,55.0,113.5,129.4$, 135.6, 155.0. 160.4.

2,2-Bis[(3-diphenylphosphanyl-4-methoxy)phenyl]propane (1): TMEDA (12.95 g, $0.11 \mathrm{~mol})$ was added to $n \mathrm{BuLi}(2.5 \mathrm{M}$ solution in hexanes) $(44.6 \mathrm{~mL}, 0.11 \mathrm{~mol})$. At $-15{ }^{\circ} \mathrm{C}$ a solution of $\mathbf{A}$ $(13.29 \mathrm{~g}, 0.052 \mathrm{~mol})$ in diethyl ether $(75 \mathrm{~mL})$ was added dropwise over a period of $1.5 \mathrm{~h}$. The mixture was allowed to slowly warm up to room temp. and was stirred for about $10 \mathrm{~h}$ to yield a yellow suspension. At $0{ }^{\circ} \mathrm{C} \mathrm{ClPPh}_{2}(24.6 \mathrm{~g}, 0.11 \mathrm{~mol})$ in hexanes $(30 \mathrm{~mL})$ was added dropwise over a period of $1 \mathrm{~h}$. Solvents were removed in vacuo and $\mathrm{CH}_{2} \mathrm{Cl}_{2}(60 \mathrm{~mL})$ was added together with saturated brine $(50 \mathrm{~mL})$. The organic phase was separated and dried with $\mathrm{MgSO}_{4}$. After filtration through celite, the solvents were removed in vacuo to yield a pink oil that solidified on standing for about $10 \mathrm{~h}$ at room temp. under argon. Ethanol $(40 \mathrm{~mL})$ was added to give an orange solution and a white precipitate. The solid was washed with ethanol, filtered, and dried. Yield 54\% (17.46 g, $28.1 \mathrm{mmol}$ ). ${ }^{1} \mathrm{H}$ NMR (400 MHz, $\left.\mathrm{CDCl}_{3}, 300 \mathrm{~K}, \mathrm{ppm}\right): \delta=1.24$ $\left(\mathrm{s}, 6 \mathrm{H}, \mathrm{CCH}_{3}\right), 3.73\left(\mathrm{~s}, 6 \mathrm{H}, \mathrm{OCH}_{3}\right), 6.40\left(\mathrm{dd},{ }^{1} J=5.2,{ }^{2} J=\right.$ $\left.2.4 \mathrm{~Hz}, 2 \mathrm{H}, \mathrm{H}^{1}\right), 6.73\left(\mathrm{dd},{ }^{1} J=8.8,{ }^{2} J=4.8 \mathrm{~Hz}, 2 \mathrm{H}, \mathrm{H}^{2}\right), 7.04$ $\left(\mathrm{dd},{ }^{1} J=8.8,{ }^{2} J=2 \mathrm{~Hz}, 2 \mathrm{H}, \mathrm{H}^{3}\right), 7.24\left(\mathrm{~m}, 20 \mathrm{H}, \mathrm{PPh}_{2}\right)$ (Numbering scheme see Figure 7). ${ }^{13} \mathrm{C}$ NMR $\left(100 \mathrm{MHz}, \mathrm{CDCl}_{3}, 300 \mathrm{~K}\right.$, ppm): $\delta=30.3\left[\mathrm{C}\left(\mathrm{CH}_{3}\right)_{2}\right], 41.6\left[\mathrm{C}\left(\mathrm{CH}_{3}\right)_{2}\right], 55.7\left(\mathrm{OCH}_{3}\right), 109.5$, $124.3,128.2\left(\mathrm{~d}, J_{\mathrm{P}, \mathrm{C}}=6.8 \mathrm{~Hz}\right), 128.3,128.4,132.4,133.7\left(\mathrm{~d}, J_{\mathrm{P}, \mathrm{C}}=\right.$ $19.8 \mathrm{~Hz}), 136.9\left(\mathrm{~d}, J_{\mathrm{P}, \mathrm{C}}=10.7 \mathrm{~Hz}\right), 143.0,159.0\left(\mathrm{~d}, J_{\mathrm{P}, \mathrm{C}}=\right.$ $14.5 \mathrm{~Hz}) .{ }^{31} \mathrm{P}\left\{{ }_{1}^{1} \mathrm{H}\right\} \mathrm{NMR}\left(162 \mathrm{MHz}, \mathrm{CDCl}_{3}, 300 \mathrm{~K}, \mathrm{ppm}\right): \delta=$ -14.8 (s). $\mathrm{C}_{41} \mathrm{H}_{38} \mathrm{O}_{2} \mathrm{P}_{2}$ : calcd. C 78.83, H 6.13; P, 9.92; found $\mathrm{C}$ 78.65, H 6.08; P, 9.98 .

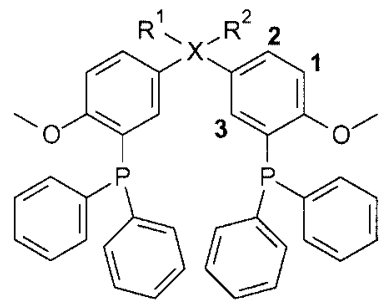

Figure 7. Numbering scheme for protons $\mathrm{H}^{1}, \mathrm{H}^{2}$, and $\mathrm{H}^{3}$ of compounds $\mathbf{1}-\mathbf{8}$

1,1-Bis[(3-diphenylphosphanyl-4-methoxy)phenyl]cyclohexane (2): Starting from B (4.99 g, $0.017 \mathrm{~mol})$, compound $\mathbf{2}$ was obtained as a white powder using the same procedure as described for compound 1. Yield $56 \%(6.34 \mathrm{~g}, 9.4 \mathrm{mmol}) .{ }^{1} \mathrm{H}$ NMR $(400 \mathrm{MHz}$, $\left.\mathrm{CDCl}_{3}, 300 \mathrm{~K}, \mathrm{ppm}\right): \delta=1.23\left(\mathrm{~m}, 6 \mathrm{H}, m, p-\mathrm{CH}_{2}, c-\mathrm{C}^{6}\right), 1.73(\mathrm{~m}$, 
$\left.4 \mathrm{H}, o-\mathrm{CH}_{2}, c-\mathrm{C}^{6}\right), 3.71\left(\mathrm{~s}, 6 \mathrm{H}, \mathrm{OCH}_{3}\right), 6.47\left(\mathrm{dd},{ }^{1} J=5.6,{ }^{2} J=\right.$ $\left.2.4 \mathrm{~Hz}, 2 \mathrm{H}, \mathrm{H}^{1}\right), 6.72\left(\mathrm{dd},{ }^{1} J=8.8,{ }^{2} J=4.8 \mathrm{~Hz}, 2 \mathrm{H}, \mathrm{Ar}-\mathrm{H}^{2}\right)$, $6.99\left(\mathrm{dd},{ }^{1} J=8.8,{ }^{2} J=2.4 \mathrm{~Hz}, 2 \mathrm{H}, \mathrm{H}^{3}\right), 7.24\left(\mathrm{~m}, 20 \mathrm{H}, \mathrm{PPh}_{2}\right)$. ${ }^{13} \mathrm{C}$ NMR $\left(100 \mathrm{MHz}, \mathrm{CDCl}_{3}, 300 \mathrm{~K}, \mathrm{ppm}\right): \delta=22.7,26.2,37.0$, 45.2, 55.6, 109.8, 125.7, 128.2, $128.3\left(\mathrm{~d}, J_{\mathrm{P}, \mathrm{C}}=13.0 \mathrm{~Hz}\right), 128.8$, $132.9,133.7\left(\mathrm{~d}, J_{\mathrm{P}, \mathrm{C}}=19.8 \mathrm{~Hz}\right), 137.0,140.9,159.0\left(\mathrm{~d}, J_{\mathrm{P}, \mathrm{C}}=\right.$ -15.2 (s). $\mathrm{C}_{44} \mathrm{H}_{42} \mathrm{O}_{2} \mathrm{P}_{2}$ : calcd. C 79.50, H 6.37; P, 9.32; found $\mathrm{C}$ 79.39, H 6.39; P, 9.31

2,2-Bis[(3-diphenylphosphanyl-4-methoxy)phenyl]ethylbenzene (3): Starting from C (12.4 g, $38.9 \mathrm{mmol})$, compound $\mathbf{3}$ was obtained as a white powder using the same procedure as described for compound 1. Yield $61 \%(16.5 \mathrm{~g}, 23.7 \mathrm{mmol}) .{ }^{1} \mathrm{H}$ NMR $(400 \mathrm{MHz}$, $\left.\mathrm{CDCl}_{3}, 300 \mathrm{~K}, \mathrm{ppm}\right): \delta=1.74\left(\mathrm{~s}, 3 \mathrm{H}, \mathrm{CCH}_{3}\right), 3.72\left(\mathrm{~s}, 6 \mathrm{H}, \mathrm{OCH}_{3}\right)$, $6.33\left(\mathrm{dd},{ }^{1} \mathrm{~J}=5.6,{ }^{2} \mathrm{~J}=2.4 \mathrm{~Hz}, 2 \mathrm{H}, \mathrm{H}^{1}\right), 6.67\left(\mathrm{dd},{ }^{1} J=8.8,{ }^{2} J=\right.$ $\left.4.8 \mathrm{~Hz}, 2 \mathrm{H}, \mathrm{H}^{2}\right), 6.81(\mathrm{~m}, 2 \mathrm{H}, o-\mathrm{CH}, \mathrm{Ph}), 6.91\left(\mathrm{dd},{ }^{1} J=8.8,{ }^{2} J=\right.$ $\left.2.4 \mathrm{~Hz}, 2 \mathrm{H}, \mathrm{H}^{3}\right), 7.07$ (m, $\left.3 \mathrm{H}, m-, p-\mathrm{CH}, \mathrm{Ph}\right), 7.18\left(\mathrm{~m}, 20 \mathrm{H}, \mathrm{PPh}_{2}\right)$. ${ }^{13} \mathrm{C}$ NMR (100 MHz, $\left.\mathrm{CDCl}_{3}, 300 \mathrm{~K}, \mathrm{ppm}\right): \delta=30.0,51.2,55.6$, $109.3,124.2\left(\mathrm{~d}, J_{\mathrm{P}, \mathrm{C}}=13.0 \mathrm{~Hz}\right), 125.5,127.6,128.2\left(\mathrm{~d}, J_{\mathrm{P}, \mathrm{C}}=\right.$ $6.8 \mathrm{~Hz}), 128.3\left(\mathrm{~d}, J_{\mathrm{P}, \mathrm{C}}=3.1 \mathrm{~Hz}\right), 130.2,133.6\left(\mathrm{~d}, J_{\mathrm{P}, \mathrm{C}}=19.8 \mathrm{~Hz}\right)$, $134.1,136.7\left(\mathrm{~d}, J_{\mathrm{P}, \mathrm{C}}=10.7 \mathrm{~Hz}\right), 141.3,149.0,159.1\left(\mathrm{~d}, J_{\mathrm{P}, \mathrm{C}}=\right.$ $14.5 \mathrm{~Hz}) .{ }^{31} \mathrm{P}\left\{{ }^{1} \mathrm{H}\right\}$ NMR $\left(162 \mathrm{MHz}, \mathrm{CDCl}_{3}, 300 \mathrm{~K}, \mathrm{ppm}\right): \delta=$ -15.3 (s). $\mathrm{C}_{46} \mathrm{H}_{40} \mathrm{O}_{2} \mathrm{P}_{2}$ : calcd. C 80.45, H 5.87; P, 9.02; found $\mathrm{C}$ 80.52, H 5.76; P, 9.05 .

Bis[(3-diphenylphosphanyl-4-methoxy)phenyl]dimethylsilane (4): Starting from D (3.00 g, $0.011 \mathrm{~mol})$, compound $\mathbf{4}$ was obtained as a white powder using the same procedure as described for compound 1. Yield $65 \%(4.58 \mathrm{~g}, 7.20 \mathrm{mmol}) .{ }^{1} \mathrm{H}$ NMR $(400 \mathrm{MHz}$, $\left.\mathrm{CDCl}_{3}, 300 \mathrm{~K}, \mathrm{ppm}\right): \delta=0.09\left[\mathrm{~s}, 6 \mathrm{H}, \mathrm{Si}\left(\mathrm{CH}_{3}\right)\right], 3.75(\mathrm{~s}, 6 \mathrm{H}$, $\left.\mathrm{OCH}_{3}\right), 6.69\left(\mathrm{dd},{ }^{1} \mathrm{~J}=8.0,{ }^{2} \mathrm{~J}=4.4 \mathrm{~Hz}, 2 \mathrm{H}, \mathrm{H}^{1}\right), 6.81\left(\mathrm{dd},{ }^{1} J=\right.$ $\left.8.0,{ }^{2} \mathrm{~J}=4.4 \mathrm{~Hz}, 4 \mathrm{H}, \mathrm{H}^{2}, \mathrm{H}^{3}\right), 7.28\left(\mathrm{~m}, 20 \mathrm{H}, \mathrm{PPh}_{2}\right) .{ }^{13} \mathrm{C} \mathrm{NMR}$ $\left(100 \mathrm{MHz}, \mathrm{CDCl}_{3}, 300 \mathrm{~K}, \mathrm{ppm}\right): \delta=-2.6,55.5,109.7,124.7$, $128.2\left(\mathrm{~d}, J_{\mathrm{P}, \mathrm{C}}=6.8 \mathrm{~Hz}\right), 128.5,129.5,133.8\left(\mathrm{~d}, J_{\mathrm{P}, \mathrm{C}}=19.8 \mathrm{~Hz}\right)$, $136.3,136.7\left(\mathrm{~d}, J_{\mathrm{P}, \mathrm{C}}=9.9 \mathrm{~Hz}\right), 139.5,161.9\left(\mathrm{~d}, J_{\mathrm{P}, \mathrm{C}}=15.9 \mathrm{~Hz}\right)$. ${ }^{31} \mathrm{P}\left\{{ }^{1} \mathrm{H}\right\}$ NMR $\left(162 \mathrm{MHz}, \mathrm{CDCl}_{3}, 300 \mathrm{~K}, \mathrm{ppm}\right): \delta=-16.1$ (s). $\mathrm{C}_{40} \mathrm{H}_{38} \mathrm{O}_{2} \mathrm{P}_{2} \mathrm{Si}$ : calcd. C 74.98, H 5.98; P, 9.67; found $\mathrm{C} 75.06, \mathrm{H}$ 5.93; P, 9.63 .

Bis(2,2'-methoxy-5,5' -cyclohexyl)diphenylphosphane Oxide (5): Ligand $2(0.65 \mathrm{~g}, 0.98 \mathrm{mmol})$ was dissolved in $\mathrm{CH}_{2} \mathrm{Cl}_{2}(25 \mathrm{~mL})$ and $\mathrm{H}_{2} \mathrm{O}_{2}$ (30 wt $\%$ aqueous solution) $(0.20 \mathrm{~mL}, 1.96 \mathrm{mmol})$ in $\mathrm{H}_{2} \mathrm{O}$ $(20 \mathrm{~mL})$ was added dropwise at $0{ }^{\circ} \mathrm{C}$ after which the two-phase system was stirred for about $10 \mathrm{~h}$ at room temp. The organic layer was washed with $0.1 \mathrm{~m} \mathrm{NaOH}$ solution $(20 \mathrm{~mL})$ and water $(20 \mathrm{~mL})$. After drying with $\mathrm{MgSO}_{4}$ and subsequent filtration, the solvent was removed in vacuo to leave a white powder. Yield $85 \%(0.58 \mathrm{~g}$, $0.83 \mathrm{mmol}$ ). ${ }^{1} \mathrm{H}$ NMR (400 MHz, $\left.\mathrm{CDCl}_{3}, 300 \mathrm{~K}, \mathrm{ppm}\right): \delta=1.46$ (s, $\left.6 \mathrm{H}, m, p-\mathrm{CH}_{2}, c-\mathrm{C}^{6}\right), 2.18\left(\mathrm{~s}, 4 \mathrm{H}, o-\mathrm{CH}_{2}, c-\mathrm{C}^{6}\right), 3.55(\mathrm{~s}, 6 \mathrm{H}$, $\left.\mathrm{OCH}_{3}\right), 6.81\left(\mathrm{dd},{ }^{1} \mathrm{~J}=8.8,{ }^{2} \mathrm{~J}=5.6 \mathrm{~Hz}, 2 \mathrm{H}, \mathrm{H}^{1}\right), 7.32\left(\mathrm{dd},{ }^{1} \mathrm{~J}=\right.$ $\left.8.8,{ }^{2} \mathrm{~J}=2.4 \mathrm{~Hz}, 2 \mathrm{H}, \mathrm{H}^{2}\right), 7.41\left(\mathrm{dt},{ }^{1} \mathrm{~J}=8.0,{ }^{2} \mathrm{~J}=2.4 \mathrm{~Hz}, 8 \mathrm{H}, o-\right.$ $\mathrm{CH}, \mathrm{PPh}), 7.51\left(\mathrm{dt},{ }^{1} J=8.4,{ }^{2} J=1.2 \mathrm{~Hz}, 4 \mathrm{H}, p-\mathrm{CH}, \mathrm{PPh}\right), 7.65$ $\left(\mathrm{d},{ }^{1} J=2.4 \mathrm{~Hz}, 2 \mathrm{H}, \mathrm{H}^{3}\right), 7.69$ (q, $\left.{ }^{1} J=4.8 \mathrm{~Hz}, 8 \mathrm{H}, m-\mathrm{CH}, \mathrm{PPh}\right)$. ${ }^{13} \mathrm{C}$ NMR (100 MHz, $\left.\mathrm{CDCl}_{3}, 300 \mathrm{~K}, \mathrm{ppm}\right): \delta=22.7,26.1,37.0$, $45.3,55.2,111.3\left(\mathrm{~d}, J_{\mathrm{P}, \mathrm{C}}=7.6 \mathrm{~Hz}\right), 128.0\left(\mathrm{~d}, J_{\mathrm{P}, \mathrm{C}}=12.3 \mathrm{~Hz}\right), 131.3$ $\left(\mathrm{d}, J_{\mathrm{P}, \mathrm{C}}=10.8 \mathrm{~Hz}\right), 132.8,133.2,133.9,141.0,158.6\left(\mathrm{~d}, J_{\mathrm{P}, \mathrm{C}}=\right.$ $3.7 \mathrm{~Hz}) .{ }^{31} \mathrm{P}\left\{{ }^{1} \mathrm{H}\right\}$ NMR $\left(162 \mathrm{MHz}, \mathrm{CDCl}_{3}, 300 \mathrm{~K}, \mathrm{ppm}\right): \delta=27.7$ (s). $\mathrm{C}_{44} \mathrm{H}_{42} \mathrm{O}_{4} \mathrm{P}_{2}$ : calcd. C 75.85, H 6.08; found $\mathrm{C} 76.04, \mathrm{H} 6.14$.

trans,trans-[PdClCH $\left.{ }_{3}-2\right]_{2}$, Complex 6: Ligand 2 (40.2 mg, 60.5 $\mu \mathrm{mol})$ and $\left[\mathrm{PdClCH}_{3}(\mathrm{cod})\right](13.9 \mathrm{mg}, 52.4 \mu \mathrm{mol})$ were dissolved in $\mathrm{CDCl}_{3}(0.5 \mathrm{~mL})$ and the solution was stirred for $2 \mathrm{~h}$ before the solution was analyzed by NMR spectroscopy. Single crystals were obtained by slow evaporation of the solvent from the NMR solution. ${ }^{1} \mathrm{H}$ NMR $\left(400 \mathrm{MHz}, \mathrm{CDCl}_{3}, 300 \mathrm{~K}, \mathrm{ppm}\right): \delta=-0.05(\mathrm{t}, 6$ $\mathrm{H}, \mathrm{PdCH}$ ), 1.26 (br. s, $12 \mathrm{H}, m, p-\mathrm{CH}_{2}, c-\mathrm{C}^{6}$ ), 1.80 (br. s, $8 \mathrm{H}, o$ $\left.\mathrm{CH}_{2}, c-\mathrm{C}^{6}\right), 3.61\left(\mathrm{~s}, 12 \mathrm{H}, \mathrm{OCH}_{3}\right), 6.71\left(\mathrm{~d},{ }^{1} \mathrm{~J}=8.0 \mathrm{~Hz}, 4 \mathrm{H}, \mathrm{H}^{3}\right)$, $7.04\left(\mathrm{~d},{ }^{1} J=8.0 \mathrm{~Hz}, 8 \mathrm{H}, \mathrm{H}^{1}, \mathrm{H}^{2}\right), 7.30\left(\mathrm{~m}, 24 \mathrm{H}, \mathrm{PPh}_{2}\right), 7.71$ (br. s, $\left.16 \mathrm{H}, \mathrm{PPh}_{2}\right) \cdot{ }^{13} \mathrm{C} \mathrm{NMR}\left(100 \mathrm{MHz}, \mathrm{CDCl}_{3}, 300 \mathrm{~K}, \mathrm{ppm}\right): \delta=$ $3.8,22.8,26.3,37.1,45.1,55.5,110.8,119.0,119.2,127.5,129.2$, 130.9, 131.6, 133.3, 135.0, 140.4, 157.9. ${ }^{31} \mathrm{P}\left\{{ }^{1} \mathrm{H}\right\} \mathrm{NMR}(162 \mathrm{MHz}$, $\left.\mathrm{CDCl}_{3}, 300 \mathrm{~K}, \mathrm{ppm}\right): \delta=25.0$ (s). $\mathrm{C}_{90} \mathrm{H}_{90} \mathrm{Cl}_{2} \mathrm{O}_{4} \mathrm{P}_{4} \mathrm{Pd}_{2}$ : calcd. $\mathrm{C}$ 65.78, H 5.52; found C 65.60, H 5.46.

trans,trans-[PtCl$\left.{ }_{2}-2\right]_{2}$, Complex 7: $\mathrm{PtCl}_{2}(170.3 \mathrm{mg}, 640.5 \mu \mathrm{mol})$ was heated to reflux in acetonitrile $(10 \mathrm{~mL})$ until the solid had completely dissolved. Ligand 2 (425.8 $\mathrm{mg}, 640.5 \mu \mathrm{mol})$ was added and the mixture stirred under reflux for about $10 \mathrm{~h}$. After cooling to room temp., the solvent was evaporated in vacuo to leave a yellow powder. Single crystals were obtained from acetone, by slow evaporation of the solvent. ${ }^{1} \mathrm{H} \mathrm{NMR}\left(400 \mathrm{MHz}, \mathrm{CDCl}_{3}, 300 \mathrm{~K}, \mathrm{ppm}\right)$ : $\delta=1.23\left(\mathrm{~m}, 12 \mathrm{H}, m, p-\mathrm{CH}_{2}, c-\mathrm{C}^{6}\right), 1.71$ (br. s, $\left.8 \mathrm{H}, o-\mathrm{CH}_{2}, c-\mathrm{C}^{6}\right)$, $3.63\left(\mathrm{~s}, 12 \mathrm{H}, \mathrm{OCH}_{3}\right), 6.67\left(\mathrm{~d},{ }^{1} J=8.0 \mathrm{~Hz}, 4 \mathrm{H}, \mathrm{H}^{1}\right), 7.00$ (br. s, 4 $\left.\mathrm{H}, \mathrm{H}^{2}\right), 7.09$ (d, ${ }^{1} J=8.8 \mathrm{~Hz}, 4 \mathrm{H}, \mathrm{H}^{3}$ ), 7.37 (br. m, $24 \mathrm{H}, \mathrm{PPh}_{2}$ ), $7.73\left(\mathrm{q},{ }^{1} J=5.6 \mathrm{~Hz}, 16 \mathrm{H}, \mathrm{PPh}_{2}\right) .{ }^{31} \mathrm{P}\left\{{ }^{1} \mathrm{H}\right\} \mathrm{NMR}(162 \mathrm{MHz}$, $\left.\mathrm{CDCl}_{3}, \quad 300 \mathrm{~K}, \quad \mathrm{ppm}\right): \delta=15.8\left(\mathrm{~s}, \quad J_{\mathrm{Pt}-\mathrm{P}}=2705 \mathrm{~Hz}\right)$. $\mathrm{C}_{88} \mathrm{H}_{84} \mathrm{Cl}_{4} \mathrm{O}_{4} \mathrm{P}_{4} \mathrm{Pt}_{2}$ : calcd. C 56.78, H 4.55; found C 56.65, H 4.45.

trans,trans-RhCl(CO)-2, Complex 8: $\left[\mathrm{RhCl}(\mathrm{CO})_{2}\right]_{2}(170.3 \mathrm{mg}, 640.5$ $\mu \mathrm{mol})$ and ligand $2(425.8 \mathrm{mg}, 640.5 \mu \mathrm{mol})$ were dissolved in $\mathrm{CH}_{2} \mathrm{Cl}_{2}(10 \mathrm{~mL})$ and the mixture was stirred for $2 \mathrm{~h}$. Evaporation of the solvent in vacuo yielded a yellow solid. Single crystals were obtained by slow diffusion of $\mathrm{CH}_{3} \mathrm{CN}$ into a $\mathrm{CH}_{2} \mathrm{Cl}_{2}$ solution of the solid. ${ }^{1} \mathrm{H}$ NMR (400 MHz, $\mathrm{CDCl}_{3}, 300 \mathrm{~K}, \mathrm{ppm}$ ): $\delta=1.20$ (br. s, $\left.12 \mathrm{H}, m, p-\mathrm{CH}_{2}, c-\mathrm{C}^{6}\right), 1.64$ (br. s, $8 \mathrm{H}, o-\mathrm{CH}_{2}, c-\mathrm{C}^{6}$ ), 3.61 (s, 12 $\left.\mathrm{H}, \mathrm{OCH}_{3}\right), 6.65\left(\mathrm{~d},{ }^{1} \mathrm{~J}=8.8 \mathrm{~Hz}, 4 \mathrm{H}\right), 6.87$ (br. s, $\left.4 \mathrm{H}\right), 7.00(\mathrm{~d}$, $\left.{ }^{1} J=6.4 \mathrm{~Hz}, 4 \mathrm{H}\right), 7.38\left(\mathrm{t},{ }^{1} J=7.2 \mathrm{~Hz}, 16 \mathrm{H}, \mathrm{PPh}_{2}\right), 7.46\left(\mathrm{q},{ }^{1} J=\right.$ $7.2 \mathrm{~Hz}, 8 \mathrm{H}, \mathrm{PPh}_{2}$ ), 7.82 (br. s, $16 \mathrm{H}, \mathrm{PPh}_{2}$ ). ${ }^{31} \mathrm{P}\left\{{ }^{1} \mathrm{H}\right\} \mathrm{NMR}$ $\left(162 \mathrm{MHz}, \mathrm{CDCl}_{3}, 300 \mathrm{~K}, \mathrm{ppm}\right): \delta=23.7\left(\mathrm{~d}, J_{\mathrm{Rh}-\mathrm{P}}=128 \mathrm{~Hz}\right)$. IR (ATR mode, solid, carbonyl region, $\left.\mathrm{cm}^{-1}\right): \tilde{v}=1976(\mathrm{RhCO})$. $\mathrm{C}_{90} \mathrm{H}_{84} \mathrm{Cl}_{2} \mathrm{O}_{6} \mathrm{P}_{4} \mathrm{Rh}_{2}$ : calcd. C 65.03, H 5.09; found C 64.88, H 4.96.

Molecular Structures of 1-3 and 5-8: The data were collected on a Nonius-Kappa CCD diffractometer with a rotating anode. The structures were solved by direct methods using SHELXS-97 (2, 3) ${ }^{[47]}$ or DIRDIF99 $(\mathbf{1}, \mathbf{6}-\mathbf{8})^{[48]}$ and refined by least-squares procedures on $F^{2}$ using SHELXL-97. ${ }^{[49]}$ All non-hydrogen atoms were refined with anisotropic displacement parameters. Hydrogen atoms were constrained to idealized geometries and allowed to ride on their carrier atoms with an isotropic displacement parameter related to the equivalent displacement parameter of their carrier atoms. Compound 3 contained one phenyl ring on one of the phosphanes which is disordered over two positions. Compound $\mathbf{6}$ contained four molecules of $\mathrm{CDCl}_{3}$ in the unit cell. Compound 7 contained two acetone molecules which were disordered over two positions. Compound $\mathbf{8}$ contained disordered dichloromethane molecules. Their contribution was taken into account using the PLATON/SQUEEZE procedure. Structure validation and molecular graphics preparation were performed with the PLATON package. ${ }^{[50]}$ Crystal data are given in Tables 6 and 7. CCDC-213681 (1), -213682 (2), -213683 (3), -213684 (5), -213685 (6), -213686 (7), and -213687 (8) contain the supplementary crystallographic data for this paper. These data can be obtained free of charge via www.ccdc.cam.ac.uk/conts/retrieving.html [or from the CCDC, 12 Union Road, Cambridge CB2 1EZ, UK; Fax: (internat.) + 441223-336033; E-mail: deposit@ccdc.cam.ac.uk]. 
Table 6. Selected crystallographic data for compounds $\mathbf{1}-\mathbf{3}$ and $\mathbf{5}$

\begin{tabular}{|c|c|c|c|c|}
\hline & 1 & 2 & 3 & 5 \\
\hline Formula & $\mathrm{C}_{41} \mathrm{H}_{38} \mathrm{O}_{2} \mathrm{P}_{2}$ & $\mathrm{C}_{44} \mathrm{H}_{42} \mathrm{O}_{2} \mathrm{P}_{2}$ & $\mathrm{C}_{46} \mathrm{H}_{40} \mathrm{O}_{2} \mathrm{P}_{2}$ & $\mathrm{C}_{44} \mathrm{H}_{42} \mathrm{O}_{4} \mathrm{P}_{2} \cdot \mathrm{H}_{2} \mathrm{O}$ \\
\hline $\mathrm{FW} / \mathrm{M}_{r}$ & 624.65 & 664.72 & 686.72 & 714.73 \\
\hline Crystal size [mm] & $0.12 \times 0.27 \times 0.42$ & $0.12 \times 0.15 \times 0.45$ & $0.21 \times 0.39 \times 0.48$ & $0.09 \times 0.21 \times 0.24$ \\
\hline Crystal system & monoclinic & monoclinic & triclinic & monoclinic \\
\hline Space group & $C 2 / c($ no. 15$)$ & $P 2_{1} / c$ (no. 14$)$ & $P \overline{1}$ (no. 2$)$ & $P 2_{1} / c$ (no. 14$)$ \\
\hline$a[\AA]$ & $28.1693(3)$ & $17.4156(2)$ & $11.1456(1)$ & $12.2410(10)$ \\
\hline$b[\AA]$ & $8.2166(1)$ & $7.8636(1)$ & $12.0144(2)$ & $11.9950(10)$ \\
\hline$c[\AA]$ & $32.3533(4)$ & $28.3503(4)$ & $15.0980(2)$ & $27.398(3)$ \\
\hline$\alpha\left[^{\circ}\right]$ & & & $89.1746(9)$ & \\
\hline$\beta\left[^{\circ}\right]$ & $115.7420(4)$ & $113.2940(10)$ & $70.6049(9)$ & $114.279(11)$ \\
\hline$\gamma\left[{ }^{\circ}\right]$ & & & $80.4301(5)$ & \\
\hline$V\left[\mathrm{~A}^{3}\right]$ & 6745.21(14) & $3566.08(8)$ & $1878.66(4)$ & $3667.1(7)$ \\
\hline$\mu\left(\mathrm{Mo}-K_{\alpha}\right)\left[\mathrm{mm}^{-1}\right]$ & 0.164 & 0.159 & 0.153 & 0.165 \\
\hline$Z$ & 8 & 4 & 2 & 4 \\
\hline$d_{\text {calcd. }}\left[\mathrm{g} \mathrm{cm}^{-3}\right]$ & 1.230 & 1.238 & 1.214 & 1.295 \\
\hline$T[\mathrm{~K}]$ & 150 & 150 & 150 & 150 \\
\hline Reflections collected & 26580 & 28637 & 27481 & 4661 \\
\hline Unique reflections $\left(R_{\mathrm{int}}\right)^{[\mathrm{a}]}$ & $7617(0.058)$ & $8121(0.055)$ & $8452(0.054)$ & $4661(0.085)$ \\
\hline Observed data $[I>2.0 \sigma(I)]$ & 5758 & 5506 & 6384 & 3645 \\
\hline$w R_{2}$ of $F^{2}$ (all data) & 0.1025 & 0.1063 & 0.1159 & 0.1921 \\
\hline$\lambda[\mathrm{A}]$ & 0.71073 & 0.71073 & 0.71073 & 0.71073 \\
\hline$R_{1}$ & 0.0411 & 0.0452 & 0.0431 & 0.0785 \\
\hline$S$ & 1.02 & 1.03 & 1.03 & 1.13 \\
\hline Min., max. residual electron density $\left[\mathrm{e} / \AA^{3}\right]$ & $-0.27,0.32$ & $-0.28,0.28$ & $-0.38,0.35$ & $-0.41,0.53$ \\
\hline
\end{tabular}

${ }^{[a]} \operatorname{Rint}=\Sigma\left[\mid F_{\mathrm{o}}{ }^{2}-F_{\mathrm{o}}{ }^{2}(\right.$ mean $\left.) \mid\right] / \Sigma\left[F_{\mathrm{o}}{ }^{2}\right] ; w R\left(F^{2}\right)=\left\{\Sigma\left[w\left(F_{\mathrm{o}}{ }^{2}-F_{\mathrm{c}}{ }^{2}\right)^{2}\right] / \Sigma\left[w\left(F_{\mathrm{o}}{ }^{2}\right)^{2}\right]\right\}^{1 / 2} ; R(F)=\Sigma\left(\| F_{\mathrm{o}}|-| F_{\mathrm{c}}||\right) / \Sigma\left|F_{\mathrm{o}}\right|$.

Table 7. Selected crystallographic data for complexes $\mathbf{6}-\mathbf{8}$

\begin{tabular}{|c|c|c|c|}
\hline & 6 & 7 & 8 \\
\hline Formula & $\mathrm{C}_{90} \mathrm{H}_{90} \mathrm{Cl}_{2} \mathrm{O}_{4} \mathrm{P}_{4} \mathrm{Pd}_{2} \cdot 4 \mathrm{CDCl}_{3}$ & $\mathrm{C}_{88} \mathrm{H}_{84} \mathrm{O}_{4} \mathrm{P}_{4} \mathrm{Pt}_{2} \cdot 2 \mathrm{C}_{3} \mathrm{H}_{6} \mathrm{O}$ & $\mathrm{C}_{90} \mathrm{H}_{84} \mathrm{O}_{6} \mathrm{P}_{4} \mathrm{Cl}_{2} \mathrm{Rh}_{2} \cdot 2 \mathrm{CH}_{2} \mathrm{Cl}_{2}$ \\
\hline $\mathrm{FW} / \mathrm{M}_{r}$ & 2124.68 & 1977.57 & 1832.13 \\
\hline Crystal size [mm] & $0.06 \times 0.12 \times 0.18$ & $0.21 \times 0.30 \times 0.36$ & $0.21 \times 0.30 \times 0.36$ \\
\hline Crystal system & triclinic & monoclinic & monoclinic \\
\hline Space group & $P \overline{1}($ no.2) & $P 2_{1} / c$ (no. 14$)$ & $P 2_{1} / c$ (no. 14$)$ \\
\hline$a[\AA]$ & $11.3951(2)$ & $14.4501(2)$ & $14.3323(10)$ \\
\hline$b[\AA]$ & $14.6487(2)$ & $19.5893(3)$ & $19.9531(12)$ \\
\hline$c[\AA]$ & $16.5314(2)$ & $16.5611(2)$ & $16.4423(19)$ \\
\hline$\alpha\left[^{\circ}\right]$ & $63.8137(6)$ & & \\
\hline$\beta\left[{ }^{\circ}\right]$ & $77.9245(6)$ & $112.0310(6)$ & $112.66(2)$ \\
\hline$\gamma\left[{ }^{\circ}\right]$ & $79.6576(8)$ & & \\
\hline$V\left(\AA^{3}\right)$ & $2409.47(6)$ & $4345.60(11)$ & 4339.1(9) \\
\hline$\mu\left(\mathrm{Mo}-K_{\alpha}\right)\left[\mathrm{mm}^{-1}\right]$ & 0.877 & 3.465 & 0.682 \\
\hline$Z$ & 1 & 2 & 2 \\
\hline$d_{\text {calcd. }}\left[\mathrm{g} \mathrm{cm}^{-3}\right]$ & 1.462 & 1.511 & 1.272 \\
\hline$T[\mathrm{~K}]$ & 150 & 150 & 150 \\
\hline Reflections collected & 37005 & 42286 & 82640 \\
\hline Unique reflections $\left(R_{\text {int }}\right)^{[\mathrm{a}]}$ & $10960(0.061)$ & $8532(0.072)$ & $9954(0.0505)$ \\
\hline Observed data $[I>2.0 \sigma(I)]$ & 8417 & 6829 & 8179 \\
\hline$w R_{z}$ of $F^{2}$ (all data) & 0.1176 & 0.1106 & 0.070 \\
\hline$\lambda[\AA]$ & 0.71073 & 0.71073 & 0.71073 \\
\hline$R_{1}$ & 0.0479 & 0.0587 & 0.029 \\
\hline$S$ & 1.07 & 1.36 & 1.05 \\
\hline Min., max. residual electron density $\left[\mathrm{e} / \AA^{3}\right]$ & $-0.73,1.17$ & $-0.91,1.40$ & $-0.49,0.37$ \\
\hline
\end{tabular}

${ }^{[\mathrm{a}]} R_{\mathrm{int}}=\Sigma\left[\mid F_{\mathrm{o}}{ }^{2}-F_{\mathrm{o}}{ }^{2}(\right.$ mean $\left.) \mid\right] / \Sigma\left[F_{\mathrm{o}}{ }^{2}\right] ; w R\left(F^{2}\right)=\left\{\Sigma\left[w\left(F_{\mathrm{o}}{ }^{2}-F_{\mathrm{c}}{ }^{2}{ }^{2}\right] / \Sigma\left[w\left(F_{\mathrm{o}}{ }^{2}\right)^{2}\right]\right\}^{1 / 2} ; R(F)=\Sigma\left(\left\|F_{\mathrm{o}}|-| F_{\mathrm{c}}\right\|\right) / \Sigma\left|F_{\mathrm{o}}\right|\right.$.

\section{Acknowledgments}

This work was financially supported by the National Research School Combination for Catalysis (NRSCC) and in part (A.M.M. and A.L.S.) by the Netherlands Foundation of Chemical Research (SON) with financial aid from the Netherlands Organisation for
Scientific Research (CW-NWO). OMG is gratefully acknowledged for a generous loan of metal precursors. We would like to thank Dr. Rafael Sablong and Dr. Christian Müller (TU/e) for scientific discussions. 
[1] C. A. Bessel, P. Aggarwal, A. C. Marschilok, K. J. Takeuchi, Chem. Rev. 2001, 101, 1031-1066.

[2] [2a] C. A. McAuliffe, Transition Metal Complexes of Phosphorus, Arsenic and Antimony Ligands; New York, 1973. [2b] C. A. McAuliffe, W. Levason, Phosphane, Arsane and Stibine Complexes of the Transition Elements; Elsevier Science: New York, 1978. [2c]D. M. A. Minahan, W. E. Hill, C. A. McAuliffe, Coord. Chem. Rev. 1984, 55, 31.

[3] W. Tang, X. Zhang, Chem. Rev. 2003, 103, 3029-3069.

[4] W. Ahlers, R. Paciello, D. Vogt, J. I. van der Vlugt (to BASF AG), US Patent Appl. 20020111517 [Chem. Abstract. 2002, 169060].

[5] J. I. van der Vlugt, J. M. Bonet, A. M. Mills, A. L. Spek, D. Vogt, Tetrahedron Lett. 2003, 44, 4389-4392.

[6] Ullmann's Encyclopedia of Industrial Chemistry, 6th electronic edition, Wiley-VCH, Weinheim, 2002

[7] ${ }^{31}$ P NMR spectroscopy in stereochemical analysis (Ed.: J. G Verkade, L. D. Quin); VCH, Weinheim, 1987.

[8] [8a] P. W. Baures, J. V. Silverton, Acta Crystallogr., Sect. C 1990, 46, 715-717. [8b] P. W. Baures, Acta Crystallogr., Sect. C 1991, 47, 2715-2716. ${ }^{[8 c]}$ C. Lariucci, R. Helena de Almeida Santos, J. R. Lechat, Acta Crystallogr., Sect. C 1986, 42, 1825-1828.

[9] M. R. Churchill, R. F. See, S. L. Randall, J. D. Atwood, Acta Crystallogr., Sect. C 1993, 49, 345-347.

${ }^{[10]}$ S. Gladiali, S. Pulacchini, D. Fabbri, M. Manassero, M. Sansoni, Tetrahedron: Asymmetry 1998, 9, 391-395.

[11] [11a] W. J. Marshall, V. V. Grushin, Organometallics 2003, 22, $555-562 .{ }^{[11 b]}$ S. Priya, M. S. Balakrishna, J. T. Mague, S. M. Mobin, Inorg. Chem. 2003, 42, 1272-1281. [11c] T.-W. Teo, S. Selvaratnam, J. J. Vittal, P.-H. Leung, Inorg. Chim. Acta 2003, $352,213-219$.

${ }^{[12]}$ T. B. Rauchfuss, F. T. Patino, D. M. Roundhill, Inorg. Chem. 1975, 14, 652-656.

${ }^{[13]}$ W. Marty, P. N. Kapoor, H. B. Bürgi, E. Fischer, Helv. Chim. Acta 1987, 70, 158-170.

${ }^{[14]}$ M. A. Zuideveld, B. H. G. Swennenhuis, M. D. K. Boele, Y Guari, G. P. F. van Strijdonck, J. N. H. Reek, P. C. J. Kamer, K. Goubitz, J. Fraanje, M. Lutz, A. L. Spek, P. W. N. M. van Leeuwen, J. Chem. Soc., Dalton Trans. 2002, 2308-2317.

${ }^{[15]}$ K. Takenaka, Y. Obora, L. H. Jiang, Y. Tsuji, Organometallics 2002, 21, 1158-1166

${ }^{[16]}$ A. Mentes, R. D. W. Kemmitt, J. Fawcett, D. R. Russeli, Polyhedron 1999, 18, 1141-1145.

${ }^{[17]}$ S. J. Young, B. Kellenberger, J. H. Reibenspies, S. E. Himmel, M. Manning, O. P. Anderson, J. K. Stille, J. Am. Chem. Soc. 1988, 110, 5744-5753.

${ }^{[18]}$ A. Pryde, B. L. Shaw, B. Weeks, J. Chem. Soc., Dalton Trans. 1976, 322-327

${ }^{[19]}$ C. E. Housecroft, B. A. M. Shaykh, A. L. Rheingold, B. S. Haggerty, Inorg. Chem. 1991, 30, 125-130.

[20] [20a] J. A. Davies, S. Dutremez, A. A. Pinkerton, M. Vilmer, Organometallics 1991, 10, 2956-2958. ${ }^{[20 b]}$ C. B. Pamplin, S. J. Rettig, B. O. Patrick, B. R. James, Inorg. Chem. 2003, 42, 4117-4126.

${ }^{[21]}$ C. J. Cobley, P. G. Pringle, Inorg. Chim. Acta 1997, 265, $107-115$

${ }^{[22]}$ N. W. Alcock, L. Judd, P. G. Pringle, Inorg. Chim. Acta 1986, 113, L13-L15.

${ }^{[23]}$ F. C. March, R. Mason, K. M. Thomas, B. L. Shaw, J. Chem. Soc., Chem. Commun. 1975, 584-585.
${ }^{[24]}$ F. E. Wood, J. Hvoslef, H. Hope, A. L. Balch, Inorg. Chem. 1984, 23, 4309-4315.

${ }^{[25]}$ B. E. Mann, C. Masters, B. L. Shaw, J. Chem. Soc. 1971, $1104-1106$

[26] P. Suomalainen, S. Jääskeläinen, M. Haukka, R. H. Laitinen, J. Pursiainen, T. A. Pakkanen, Eur. J. Inorg. Chem. 2000, $2607-2613$

${ }^{[27]}$ M. J. Atherton, K. S. Coleman, J. Fawcett, J. H. Holloway, E. G. Hope, A. Karaçar, L. A. Peck, G. C. Saunders, J. Chem. Soc., Dalton Trans. 1995, 4029-4038.

[28] L. Vaska, J. Peone Jr., J. Chem. Soc., Chem. Commun. 1971, $418-419$

[29] K. G. Moloy, J. L. Petersen, J. Am. Chem. Soc. 1995, 117, 7696-7710

${ }^{[30]}$ F.-B. Xu, Q.-S. Li, X.-S. Zeng, X.-B. Leng, Z.-Z. Zhang, Organometallics 2002, 21, 4894-4896.

[31] J. R. Dilworth, Y. Zheng, D. V. Griffiths, J. Chem. Soc., Dalton Trans. 1999, 1877-1882.

${ }^{[32]}$ C. M. Thomas, R. Mafua, B. Therrien, E. Rusanov, H. StœckliEvans, G. Süss-Fink, Chem. Eur. J. 2002, 8, 3343-3352.

${ }^{[33]}$ T. W. Graham, A. Llamazares, R. McDonald, M. Cowie, Organometallics 1999, 18, 3502-3510.

${ }^{[34]}$ N. W. Alcock, J. M. Brown, J. C. Jeffery, J. Chem. Soc., Dalton Trans. 1977, 888-893.

${ }^{[35]}$ M. Cowie, S. K. Dwight, Inorg. Chem. 1980, 19, 2500-2507.

${ }^{[36]}$ A. L. Balch, L. A. Fossett, M. M. Olmstead, D. E. Oram, P. E. Reedy Jr., J. Am. Chem. Soc. 1985, 107, 5272-5274.

${ }^{[37]}$ X. Liu, A. H. Eisenberg, C. L. Stern, C. A. Mirkin, Inorg. Chem. 2001, 40, 2940-2941.

${ }^{[38]}$ M. F. M. Al-Dulaymmi, D. L. Hughes, R. L. Richards, J. Organomet. Chem. 1992, 424, 79-86.

${ }^{[39]}$ M. Cowie, S. K. Dwight, A. R. Sanger, Inorg. Chim. Acta 1978 , 31, L407-L409.

${ }^{[40]}$ D. R. Drew, J. R. Doyle, Inorg. Synth. 1990, 28, 346-349.

${ }^{[41]}$ F. T. Ladipo, G. K. Anderson, Organometallics 1994, 13, 303-306.

${ }^{[42]}$ H. C. Clark, L. E. Manzer, J. Organomet. Chem. 1973, 59 , $411-428$.

[43] [43a] N. Yonezawa, T. Hino, Y. Tokita, K. Matsuda, T. Ikeda, Tetrahedron 1997, 53, 14287-14296. ${ }^{[43 b]}$ S. H. Dai, C. Y. Lin, D. V. Rao, F. A. Stuber, P. S. Carleton, H. Ulrich, J. Org. Chem. 1985, 50, 1722-1725.

${ }^{[44]}$ B. Gerharz, G. Meier, E. W. Fischer, J. Chem. Phys. 1990, 92, $7110-7122$

${ }^{[45]}$ I. E. Marko, J. M. Southern, M. L. Kantam, Synlett 1991, 4, 235-237. ${ }^{[45 a]}$ I. E. Marko, M. L. Kantam, Tetrahedron Lett. 1991, 32, 2255-2258.

[46] [46a] A. Studer, M. Bossart, T. Vasella, Org. Lett. 2000, 2, 985-988. ${ }^{[46 b]}$ C. A. van Walree, X. Y. Lauteslager, A. M. A. van Wageningen, J. W. Zwikker, L. W. Jenneskens, J. Organomet. Chem. 1995, 496, 117-125.

[47] G. M. Sheldrick, SHELXS-97. University of Göttingen, Germany, 1997.

${ }^{[48]}$ P. T. Beurskens, G. Beurskens, R. de Gelder, S. Garçia-Granda, R. O. Gould, R. Israel, J. M. M. Smits, The DIRDIF99 Program System, University of Nijmegen, The Netherlands, 1999.

${ }^{[49]}$ G. M. Sheldrick, SHELXL-97. University of Göttingen, Germany, 1997.

${ }^{[50]}$ A. L. Spek, PLATON, A Multipurpose Crystallographic Tool, Utrecht University, The Netherlands, 2002.

Received June 30, 2003

Early View Article

Published Online October 10, 2003 